\title{
Fim da direita envergonhada? Atuação da bancada evangélica e da bancada da bala e os caminhos da representação do conservadorismo no Brasil
}

\author{
Marcos Paulo dos Reis Quadros ${ }^{1}$ \\ Rafael Machado Madeira ${ }^{2}$ (D)
}

\begin{abstract}
Nos últimos anos, a reação de grupos de direita/conservadores ao avanço de "pautas progressistas" é um dos temas que mais tem despertado o interesse de pesquisadores da ciência política no Brasil. O presente artigo busca contribuir para esse debate, analisando, no âmbito da Câmara dos Deputados, a atuação de lideranças de dois dos principais vetores dessa agenda conservadora: a bancada evangélica e a bancada da bala. Para tanto, o artigo examina discursos e projetos de lei formulados por parlamentares entre 2010 e 2017, argumentando que, se ainda não é possível afirmar que o fenômeno da "direita envergonhada" está perdendo força de modo generalizado na Câmara dos Deputados, destaca-se um grupo de deputados bastante ativo e ideologizado, relativamente desvinculado das famílias políticas tradicionais e capaz de mobilizar abertamente categorias identitárias ligadas à direita e/ou ao conservadorismo.
\end{abstract}

Palavras-chave: conservadorismo; direita; bancada evangélica; bancada da bala; discurso

\section{Introdução}

Ao analisar o posicionamento ideológico dos deputados constituintes em meados da década de 1980, Rodrigues (1987) constata:

Quando se trata de se autodefinirem ideologicamente, os parlamentares evitam as posições mais radicais, e se situam um pouco mais para a esquerda. No conjunto, a esquerda ("extrema-esquerda", "esquerda" mais "centro-esquerda") tem mais da metade da Constituinte, enquanto a direita ("extrema-direita", "direita" e "centro-direita") praticamente desaparece, tal como evidenciamos em nossa pesquisa. A julgar pela autodefinição política dos deputados, o Brasil seria um país sem direita (Rodrigues, 1987, p. 99).

De um total de 428 deputados entrevistados pelo autor, nenhum se declarou como pertencente à "extrema-direita" e apenas $6 \%$ identificaram-se com a "centro-

\footnotetext{
${ }^{1}$ Centro Universitário da Serra Gaúcha, Caxias do Sul (RS), Brasil. E-mail: <marcosrq@hotmail.com>.

2 Pontifícia Universidade Católica do Rio Grande do Sul, Porto Alegre (RS), Brasil.

E-mail: <rafaelmachadomadeira@gmail.com>.
} 
direita". Por outro lado, 37\% dos parlamentares assumiram uma posição de "centro", $52 \%$ de "centro-esquerda" e 5\% se definiram como adeptos da "extrema-esquerda" (Rodrigues, 1987, p. 97).

Já na segunda metade da década de 1990, Pierucci (1999) analisa o mesmo fenômeno e afirma:

Não obstante o uso generalizado da dimensão direita/esquerda no linguajar dos estratos politizados da cidadania brasileira, existe aqui uma acentuada assimetria no modo de ambos os lados se autorrepresentarem. É que, à esquerda, não Ihe incomoda aparecer como tal, antes, Ihe agrada; os políticos de direita, por sua vez, têm o reflexo de se esconder como tais. Enquanto a esquerda se exibe como esquerda, sobretudo os da esquerda radical, assumindo com ares às vezes provocativos nome e orientação, os homens de direita que se declaram de direita, que 'se assumem', são bem raros (Pierucci, 1999, p. 72-73).

As manifestações do fenômeno identificadas por Rodrigues (1987) e Pierucci (1999) são apreendidas de forma sistemática por Power e Zucco Jr. (2009) e Zucco Jr. (2011), que avaliam dados oriundos de seis baterias de surveys aplicadas no Congresso Nacional entre 1990 e 2009. A partir de quase mil questionários, os autores traçam a posição ideológica na qual os parlamentares situam os principais partidos políticos brasileiros. Dados da pesquisa demonstram que " $88 \%$ dos parlamentares se posicionam à esquerda da reputação de seu partido"3 e, "enquanto apenas 13,5\% dos parlamentares se colocam à direita de onde colocam seus próprios partidos, $25,5 \%$ se colocam mais à esquerda" (Zucco Jr., 2011, p. 43-44). Logo, não se vincular ao rótulo "direita" parecia ser um aspecto fundamental para os parlamentares.

Diante disso, "o curioso - e que merece ser estudado - é saber por que, mesmo depois de mais de duas décadas, esse 'desconforto' continua existindo" (Zucco Jr., 2011, p. 44). Nesse sentido,

Rodrigues's findings were later extended by Power (2000) and Mainwaring, Power, and Meneguello (2000), but both of these studies speculated that the phenomenon of the direita envergonhada might dissipate over time. It was hypothesized that the Brazilian right might become less evasive and obfuscating as memories of the repressive 1964-1985 military regime faded and conservative parties carved out a new political identity under the aegis of neoliberal reform. However, our analysis of five waves of survey research shows that far from being a period effect (i.e., a fleeting symptom of a post authoritarian hangover), the phenomenon of the direita envergonhada is a

\footnotetext{
3 Os autores entendem "reputação" como a posição média do partido de acordo com a classificação empreendida pelos respondentes de outros partidos.
} 
remarkably durable facet of elite political culture in Brazil. For brevity, in the subsequent analysis we show results only for the first and last surveys. Results are similar for all surveys (...) (Power e Zucco Jr., 2009, p. 235).

A associação do termo "direita" ao regime civil-militar (1964-1985) sempre foi um elemento destacado pela literatura para explicar o fenômeno da "direita envergonhada". Power (2008) pode ter acertado ao afirmar que a mudança geracional contribuiria para enfraquecer o sentimento da "direita envergonhada". Porém, mesmo a agenda econômica (liberalizante) dos anos 1990 não permitiu que a direita brasileira recriasse sua identidade (Power e Zucco Jr., 2009). Podemos estar agora testemunhando esse processo, que seria explicitado a partir da mobilização da agenda moral - mote crescentemente acionado a partir dos anos 2010 (campanha eleitoral de Serra e eleição e atuação de determinadas lideranças na Câmara dos Deputados a partir de 2011) - e das demandas por políticas mais enérgicas na área da segurança pública. Essa é uma das hipóteses que se pretende testar no presente artigo.

Para o mais, propomos explorar sob outra perspectiva a tese de Power e Zucco Jr. (2009), uma vez que, se somente a mudança geracional pode não ter sido suficiente para que a direita se assumisse enquanto direita, talvez esteja na mudança do perfil dos parlamentares um dos motivos que ajudam a explicar a maior probabilidade de estes (que não tiveram absolutamente nenhum envolvimento político direto com o período do regime militar) se assumirem como "direitistas".

Soma-se a isso o fato de que o ambiente sociopolítico recente vem se mostrando mais promissor à renovação do discurso de direita no Brasil. Por um lado, as quatro vitórias sucessivas do Partido dos Trabalhadores nas eleições presidenciais estimulariam setores da oposição na busca de alguma ressignificação a fim de se manterem como players viáveis. Por outro, determinadas políticas públicas propostas pelos governos Lula e Rousseff produziram franca antipatia em alguns grupos sociais, de modo que a emergência de líderes menos afeitos às ideias progressistas e que advogassem, mediante algum grau de ideologização, a representação do eleitorado antipetista tornou-se um fruto quase previsível. Finalmente, mais um combustível para as direitas foi a grave crise política que se cristalizou a partir das investigações da Operação Lava-Jato, as quais conferiram fôlego a manifestações de massa protagonizadas por um "conjunto de atores que ao longo dos anos têm buscado desafiar essa hegemonia da esquerda, imprimindo novos contornos aos protestos de rua no Brasil" (Tatagiba, Trindade e Teixeira, 2015, p. 197).

O presente artigo, repita-se, se insere nesse debate, buscando testar a hipótese de que a "direita envergonhada" está sendo superada pela atuação de deputados vinculados a grupos/perfis bem definidos: a bancada da bala e a bancada evangélica. Por meio dessa atuação, categorias como "direita", "conservadorismo" e "esquerda" (essa última utilizada enquanto ataque) passam a ganhar espaço como identidades a serem 
mobilizadas, reivindicadas e instrumentalizadas politicamente por lideranças também na Câmara dos Deputados (e mesmo por pretendentes à presidência da República).

Importa, portanto, analisar as chamadas bancada evangélica e bancada da bala na Câmara dos Deputados de modo especial, buscando visualizar como algumas das suas lideranças se valem de imagens e identidades para ocupar o espaço político facultado por extratos conservadores da população. É preciso deixar claro que a investigação não parte do pressuposto (equivocado) de que todos os deputados vinculados às religiões evangélicas $^{4}$ ou à segurança pública sejam, necessariamente, conservadores ou de direita. De igual modo, não se pretende afirmar que se trata de um grupo orgânico. Tentando evitar o risco de reificar o objeto de análise, sugere-se apenas que a "reação conservadora" a pautas "progressistas" e "subversivas" é o mote para que se crie um espaço no qual lideranças ligadas a essas identidades possam se colocar "à frente" desses grupos, na defesa de valores tradicionais ordinariamente associados às direitas de cariz conservador. Nesse particular, o artigo deter-se-á principalmente no exame dos discursos dos deputados, bem como na análise de projetos de lei e na repercussão pública de alguns dos debates de grande impacto daí decorrentes.

A pesquisa pondera que ainda é cedo para avaliar se o discurso dessas lideranças representará apenas uma reação conservadora mais pontual, ou se terá fôlego para constituir-se em amálgama a partir do qual surgirá um discurso mais articulado, com maior capacidade de interpelação e mais propositivo. Contudo, sugere-se que o ganho de espaço midiático que essa agenda teve nos últimos anos pode configurar terreno fértil para que a direita no Brasil (ou pelo menos parte dela) passe a se assumir enquanto direita.

Antes, porém, convém esclarecer alguns conceitos, de modo a dialogar com a literatura existente e definir alguns dos pressupostos teóricos que embasam este artigo.

\section{Direitas e conservadorismos: breves definições}

As discussões teóricas acerca dos significados e valores das diferentes correntes político-ideológicas são controversas e há muito vêm merecendo atenção por parte da ciência política. Diante da complexidade do debate e da extensão da literatura, neste restrito espaço almeja-se apenas explicitar as linhas conceituais basilares que amparam os pressupostos do presente artigo no que diz respeito ao emprego dos termos "direita" e "conservadorismo".

No que se refere ao exame da díade direita-esquerda, o clássico trabalho de Bobbio (1995) é incontornável. Mesmo reconhecendo o pluralismo existente no interior de ambas as correntes, Bobbio elenca critérios que seriam capazes de cristalizar a essência de cada polo do espectro ideológico. Assim, em suma, sustentou que, enquanto

\footnotetext{
${ }^{4}$ Neste artigo, analisamos apenas os evangélicos, o que não nos permite tecer interpretações com base na chamada "bancada da bíblia".
} 
a direita tende a bater-se sobretudo pelos valores da tradição e da hierarquia, a esquerda defende prioritariamente as ideias de emancipação e igualdade.

Em acréscimo, Lukes (2003) enceta o "princípio da retificação" como distinção fundamental. Nessa acepção, a esquerda busca a retificação da ordem social/status quo a fim de minimizar (ou, dependendo do caso, abolir) as desigualdades, ao passo que a direita, cética em relação às mudanças repentinas, teme que os resultados práticos da retificação descambem em desordem e na fragilização da liberdade, optando, a priori, pela preservação.

Mesmo com base em definições genéricas, de acordo com Bobbio, "precisamos partir da convicção de que a distinção clássica entre direita e esquerda ainda tem razão de existir", já que, "não obstante as velhas e novas rejeições, continuamos a usar as palavras direita e esquerda na linguagem política corrente como se ainda significassem alguma coisa. E é evidente que, se continuamos a nos entender quando as usamos, é porque possuem algum significado" (Bobbio, 1995, p. 150).

Acatando essas sugestões, julgamos que um dos conceitos centrais para o presente artigo, o conservadorismo, está vinculado diretamente à categoria "direita". Com efeito, veremos que os princípios da ordem e do ceticismo diante da retificação estão presentes no conservadorismo em geral e no discurso de grupos que parecem levantar a bandeira da direita conservadora no Brasil dos dias que correm. É certo que podem existir direitas que se afastam do conservadorismo em sentido pleno (como é o caso dos liberalismos mais radicais e de linhagens nacional-revolucionárias igualmente extremistas), mas, segundo a classificação geral da literatura, um imaginado conservadorismo ideologicamente de esquerda soaria como contrassenso ${ }^{5}$. Como complemento, se introduz, a exemplo de Freeden (2003), a ideia de que, em realidade, existiriam "macroideologias" (liberalismo, conservadorismo, socialismo e fascismo) e suas derivações, as "microideologias" (tais como libertarianismo e neoliberalismo, democracia cristã e neoconservadorismo, social-democracia e anarquismo, hitlerismo e franquismo etc.). Porém, é dos dois troncos primeiros (esquerda e direita) que brotam os ramos "macroideologias" e "microideologias", sendo o conservadorismo e suas derivações descendentes da direita.

Como se poderia ilustrar, em poucas linhas, o desenho geral do "ramo" conservador? Edmund Burke pode ser considerado o motor primeiro do conservadorismo em sua forma moderna, a partir da reação que desenvolveu diante da Revolução Francesa. Seria precipitado, contudo, pretender firmar um rótulo no pensador irlandês

\footnotetext{
5 Resta, como exceção, a interpretação situacional ou posicional levantada por Vicent (1995), segundo a qual se entende por conservadorismo qualquer ato político deliberado que vise barrar a mudança. No extremo dessa acepção, o partido comunista cubano, por exemplo, poderia ser conservador, uma vez que se esforça para manter o status quo do regime que coordena desde 1959, enquanto os grupos liberais ou conservadores existentes na clandestinidade cubana ocupariam o lugar do progressismo justamente por defenderem o rompimento com o status quo. Como se percebe, trata-se de uma análise completamente desideologizada, que, julgamos, confunde a compreensão de determinados fenômenos políticos.
} 
segundo o léxico contemporâneo, utilizando-se, por exemplo, de termos como "reacionário". De fato, "o autor das Reflexões sobre a revolução em França não pertencia às fileiras dos tories, mas às dos whigs, cujo discurso, diferentemente, se caracterizava pela defesa do governo parlamentar e das minorias religiosas", sendo que, "para Burke, a política não era uma ciência abstrata, racionalista e universalista, mas uma arte voltada para a resolução de problemas práticos. O estadista não era um especulador metafísico" (Lynch, 2017, p. 318).

Logo, percebe-se que o conservadorismo moderno emerge justamente contestando o princípio da retificação, o qual, conforme Lukes, guiaria as esquerdas. Burke combate as doutrinas revolucionárias do iluminismo francês, os arquitetos sociais, a ruptura revelada pelos "conspiradores literatos e filósofos intrigantes", "teólogos políticos" e "políticos teólogos" (Burke, 2014, p. 33), preferindo antes o ceticismo. Nas palavras de Russel Kirk, ele mesmo um conhecido conservador, "a política é a arte do possível, diz o conservador: ele pensa nas políticas de Estado como as que intentam preservar a ordem, a justiça e a liberdade" (Kirk, 2014, p. 91).

Daí que o conservadorismo também mantenha aderência ao valor da tradição, que, para Bobbio, seria indispensável às direitas. Com efeito, João Camilo de Oliveira Torres destaca a tradição como elemento central do conservadorismo, "uma posição política que reconhece que a existência das comunidades está sujeita a determinadas condições, e que as mudanças sociais, para serem justas e válidas, não podem quebrar a continuidade entre o passado e o futuro", porque "não considera viáveis as mudanças feitas sem o sentido de continuidade histórica" (Torres, 2016, p. 40).

Se a manutenção da tradição não equivale a mero imobilismo, o conservadorismo igualmente supõe que a desigualdade é natural, não cabendo aos movimentos políticos reivindicação voltada a eliminá-la. Para os conservadores, "exceto em um último senso moral, os homens são desiguais. A organização social é complexa e sempre inclui uma variedade de classes, ordens e grupos. Diferenciação, hierarquia e liderança são características inevitáveis de qualquer sociedade civil" (Huntington, 1957, p. 456).

Finalmente, consideramos pertinente contemplarmos o conservadorismo também à luz da "tese da ameaça" proposta por Hirschman (1992). Em A retórica da intransigência, o autor argumenta que os conservadores, ao considerarem que o custo social de determinadas reformas é alto demais porque "coloca em perigo outra preciosa realização anterior" (Hirschman, 1992, p. 15), tendem a reagir sempre que os interesses que defendem estão em causa.

Assim, adota-se, no presente artigo, os termos "direita" e "conservadorismo" no sentido em que possam refletir os parâmetros interpretativos dos autores acima citados, destacando-se as ideias de tradição (manutenção da ordem), hierarquia (oposição à igualdade), ceticismo diante da retificação e reação em face da "ameaça". É evidente que desconsideramos uma qualificadíssima gama de estudiosos cujos trabalhos 
enriqueceriam muito a análise ${ }^{6}$. Contudo, presume-se que os aportes já elencados sejam suficientes para examinarmos também à luz da teoria os objetos centrais da pesquisa.

\section{Gênese de uma onda conservadora?}

Quando se fala em representação política, a complexa relação entre partidos políticos e posicionamento (e/ou reputação) ideológico se constitui em um dos temas centrais de análise. Nesse contexto, Quadros (2015) busca lançar luzes sobre um dos paradoxos que marcam a política eleitoral e partidária brasileira desde a redemocratização: a ausência de partidos de porte médio ou grande que mobilizem de forma sistemática identidades alinhadas aos "conservadorismos" e às "direitas". Ainda assim, é temerário afirmar que esses valores não são representados. Em alguma medida isso acontece, mas eles não são (ou não eram) apresentados de forma ostensiva, sistemática e voltada à busca por forjar identidades mais claras (ao menos nas eleições presidenciais que marcaram as primeiras décadas da transição).

Apesar disso, o jornal Folha de S. Paulo, ao realizar um balanço das eleições de 2014 para o Congresso Nacional, afirmou:

Congressistas que defendem agendas conservadoras ganharam força na Câmara nas eleições. Estimativas apontam aumento dos integrantes das bancadas evangélica, ruralista e "policial". A configuração deve dificultar o debate de leis liberalizantes, como a legalização do aborto e das drogas, e da pauta ambiental e indígena (Folha de S. Paulo, 2014).

Defensores de valores cristãos, da preservação do status quo nas zonas rurais e do incremento da repressão à criminalidade passaram a ocupar mais assentos no parlamento brasileiro (a chamada "bancada BBB" - Bíblia, Boi e Bala), ao passo que bancadas simpáticas às pautas "progressistas" sofreram sensível redução. Analisando tal cenário, o presidente do Departamento Intersindical de Assessoria Parlamentar (Diap) chegou a afiançar, um dia após a eleição de outubro de 2014, que "o novo Congresso é o mais conservador desde 1964" (Queiroz, 2014). Atuando de forma mais ostensiva, a direita galga espaços crescentes de representação, o que estaria tornando o Legislativo "mais parecido com o Brasil" (Sakamoto, 2014).

Parece importante ponderar que sentenças de natureza similar àquelas proferidas pelo presidente do Diap possivelmente estejam embriagadas pelo afoitamento ou por paixões naturalmente emanadas de uma eleição bastante disputada, uma vez que é difícil supor que o parlamento eleito em 1982, por exemplo, tenha sido menos conservador do que o atual. A fim de nos determos nesse exemplo, era imenso o poder dos parlamentares oriundos da Arena ("ex-arenistas") no Congresso Nacional eleito em

6 Sobre o conservadorismo em especial, poder-se-ia citar, pelo menos, Mannheim et al. (1986), Nisbet (1987), Coutinho (2014) e Scruton (2015). 
1982, conforme Madeira (2006). Sendo composto em grande medida por apoiadores do regime militar, é plausível inferir que não se tratava de um Legislativo tendente ao progressismo. Caberia supor, por exemplo, que os deputados federais então eleitos (ou em qualquer outra das legislaturas anteriores e posteriores a 1982) fossem mais abertos a discutir a legalização das drogas, ou fossem mais receptivos à pauta do aborto e aos direitos homoafetivos?

A questão que importa e que dificulta a comparação entre legislaturas (e, portanto, afirmações como as do presidente do Diap) é que o que na época era considerado como "progressista" ou como "conservador" não eram essas pautas. Agendas como o combate à homofobia, a descriminalização do aborto e a legalização das drogas (entre outras) não faziam parte da discussão política daquele momento (e, se fizessem, é difícil supor que teriam menor resistência naquela legislatura em comparação com a atual).

Argumenta-se aqui que parte da explicação para a recente mobilização conservadora é justamente o avanço de pautas progressistas introduzidas com relativo êxito no Executivo, no Legislativo e no Judiciário durante a última década e meia. A exemplo das já citadas contribuições de Hirschman (1992), mudanças vistas como prejudiciais serviriam para o conservadorismo como um impulsionador da reação, o que o impeliria a partir de modo mais assertivo para a defesa de bandeiras que até bem pouco tempo não eram questionadas politicamente de forma tão sistemática (definição tradicional de família, por exemplo). Com efeito, fatos como o reconhecimento do valor legal da união estável entre pessoas do mesmo sexo e da utilização de células-tronco embrionárias para pesquisas científicas certamente ajudam a compreender a força mobilizadora do discurso conservador atualmente.

Essa "reação conservadora", tradicionalmente caracterizada como "uma resistência articulada, sistemática e teórica à mudança" (Huntington, 1957, p. 461, tradução nossa), teria nos parlamentares de bancadas como a evangélica a sua ponta de lança. Isto é, os conservadores, "forçados" à mobilização e cientes de que deve haver uma parcela da população que também tende ao descontentamento, passam a abandonar a "vergonha" que o pertencimento à direita outrora pode ter gerado.

Já que um dos polos da emergente agenda conservadora na atualidade é justamente a bancada evangélica, é imperativo avaliá-la.

\section{De "lugar do satanás" a "irmão vota em irmão": o crescimento dos evangélicos na Câmara dos Deputados}

A estrutura dos laços entre atores políticos e religiosos modificou-se significativamente desde o início da redemocratização. Houve uma considerável mutação no mapa religioso do Brasil, o que desencadeou reflexos na política e fez com que o 
chamado "mercado religioso"7 impusesse seu cetro: conforme o IBGE de 2010, o percentual de brasileiros que se filiam ao catolicismo decai significativamente, ao passo que aumenta o contingente associado a outros credos cristãos. Na medição do instituto, $22,2 \%$ dos brasileiros declararam-se "evangélicos"8 (o número era de 15,4\% dez anos antes, o que representa $61,4 \%$ de crescimento, cabendo acrescentar que em 1991 o percentual de fiéis dessa matriz religiosa compunha $9 \%$ da população, e apenas $6,6 \%$ em 1980). De acordo com pesquisas um pouco mais recentes (Pew Research Center, 2014), o percentual de "evangélicos" no Brasil é ainda maior ( $26 \%$ da população), o que talvez sugira que o potencial de crescimento desse segmento ainda não esteja totalmente exaurido.

Mas a ampliação encontraria correspondência mais árdua no campo da representação política caso não existisse o suporte de ações articuladas. Com efeito, ao contrário da apatia que parece ter impregnado extratos conservadores no período imediatamente posterior à redemocratização, os evangélicos de origem pentecostal se fizeram representar efetivamente na esfera política. A partir de um perfil militante que talvez esteja inspirado na tendência ativa que exige a apologética religiosa e as ações de conversão que caracterizam tais igrejas, ergue-se um lema emblemático: "irmão vota em irmão"9. A política, anteriormente vista como lugar profano, "de satanás", indigno para os crentes (Cowan, 2014) ${ }^{10}$, transforma-se em arena legítima para buscar a materialização das demandas dos evangélicos.

Desde a Assembleia Constituinte, setores pentecostais forjam seu braço político de modo metódico, apelando ao rebanho de fiéis a fim de frear as agendas laicas e, por vezes, também as católicas (Mariano, 2011). Visava-se, por um lado, assegurar a preservação de interesses doutrinários relacionados à moral e aos costumes, merecendo destaque a proibição do aborto e da união civil entre homossexuais; por outro, suprir as necessidades operacionais das igrejas, cabendo citar os pleitos pelas concessões para emissoras de comunicação (que se mostraram cruciais para a propagação da "palavra") e

\footnotetext{
7 Um dos trabalhos que bem detalham o conceito é o de Jungblut (2012).

8 O grupo denominado "evangélico" pelo IBGE agrega o protestantismo tradicional/"de missão" (luteranos, adventistas, batistas, presbiterianos etc.) e as igrejas pentecostais e neopentecostais, embora seja claro que a expansão realmente significativa tenha se desenvolvido nestas últimas (as maiores na atualidade são, em ordem de número de fiéis, Assembleia de Deus, Congregação Cristã do Brasil, Igreja Universal do Reino de Deus, Igreja do Evangelho Quadrangular e Deus é Amor).

9 A frase intitula o livro de Josué Sylvestre, publicado em 1987. Sylvestre, além de líder da igreja Assembleia de Deus, trabalhava como assessor parlamentar no período da Constituinte.

10 Como Cowan faz notar, os pentecostais brasileiros, antes dos anos 1980, tendiam a buscar afastar-se das coisas mundanas, o que inclui a política: "(...) de acordo com as prescrições evangélicas tradicionais, os crentes devem, cuidadosamente, mesmo obsessivamente, evitar as coisas deste mundo. Isso significava, explicitamente, a negação da política e do político. Ou seja, durante a maior parte da história dos evangélicos no Brasil, a política mundana provocava não só desaprovação, mas aversão visceral. A máxima "a César o que é de César e a Deus o que é de Deus" aparecia como um refrão frequente, quase reflexivo, uma advertência aos fiéis à gestão degradada dos assuntos terrestres" (Cowan, 2014, p. 107).
} 
os projetos que permitem isenções fiscais para movimentações financeiras das instituições religiosas e de seus líderes ${ }^{11}$.

O raciocínio é manifesto: se o jogo político pode vir a pôr em causa os valores e interesses evangélicos, cabe aos "irmãos" (fiéis pentecostais) votarem em "irmãos" (pastores e demais líderes indicados pelas igrejas) para fazerem representar seus desejos no parlamento e no arcabouço legal:

Os pentecostais abandonaram sua tradicional autoexclusão da política partidária, justificando seu inusitado ativismo político - antes proibitivo, porque tido como mundano e diabólico - com a alegação de que urgia defender seus interesses institucionais e seus valores morais contra seus adversários católicos, homossexuais, "macumbeiros" e feministas na elaboração da carta magna. Para tanto, propuseram-se as tarefas de combater, no Congresso Nacional, a descriminalização do aborto e do consumo de drogas, a união civil de homossexuais e a imoralidade, de defender a moral cristã, a família, os bons costumes, a liberdade religiosa e de culto e de demandar concessões de emissoras de rádio e tevê e de recursos públicos para suas organizações religiosas e assistenciais (Pierucci, 1989; Freston, 1993). Os pentecostais, ao mesmo tempo em que faziam referência ao tradicional adversário católico, aludiam a seus adversários laicos, como justificativa para "irmão votar em irmão", seu novo lema (Mariano, 2011, p. 250-251).

De fato, ainda que deixemos à margem parlamentares evangélicos que atuam em Câmaras de Vereadores e Assembleias Legislativas estaduais ${ }^{12}$, a Frente Parlamentar Evangélica (FPE), ou simplesmente a bancada evangélica, dilatou-se ao longo dos anos no parlamento brasileiro, especialmente na Câmara dos Deputados. Embora certos dados sempre demandem relativização - já que é um tanto inseguro asseverar que determinado parlamentar, embora possa declarar-se evangélico, de fato atue em uníssono com o restante da bancada em questões doutrinárias e/ou de fé - , o fato é que depois das eleições de 2014 o número de deputados com esse perfil novamente

11 Em junho de 2015, por exemplo, parlamentares evangélicos, juntamente com "os pastores Silas Malafaia, da Assembleia de Deus Vitória em Cristo, e Robson Rodovalho, da Sara Nossa Terra, participaram da articulação com o então vice-presidente Michel Temer" a fim de garantir, com êxito, um dispositivo que anula autuações fiscais da ordem de R\$300 milhões impostos às igrejas evangélicas, além de definir que os valores recebidos pelos pastores à margem do salário ficam livres de qualquer tributação (Folha de $S$. Paulo, 6 jun. 2015).

12 A presença dos evangélicos nos Legislativos estaduais é certamente significativa, mas requereria uma pesquisa de maior fôlego para ser mensurada na integralidade. Desconhecemos estudos que tenham pretendido traçar um panorama geral. É possível, no entanto, citar exemplos de pesquisas que focaram em apenas um estado da federação. É o caso de Machado (2006), que afirmou que a Assembleia Legislativa do Rio de Janeiro possuía 37\% de seus deputados ligados a igrejas. De igual modo, Miranda (2006) demonstrou o influxo evangélico no Legislativo cearense. 
aumentou, passando para 74 deputados, conforme levantamento do Diap (2014) $)^{13}$. Em acréscimo, os evangélicos chegaram a ter um de seus membros, Eduardo Cunha (PMDBRJ), no posto decisório mais importante da Casa: a presidência.

Na legislatura eleita em 2014, 31 deputados da bancada evangélica estão alocados no PRB, no PR e no PSC ${ }^{14}$. Os demais parlamentares estão espalhados em nada menos que 20 partidos, compreendendo praticamente todo o espectro ideológico. Alguma fragmentação ocorre também quando o filtro é a igreja a qual pertence cada deputado. Ainda que 24 pertençam à Assembleia de Deus e 12, à Igreja Universal do Reino de Deus, os demais parlamentares da bancada estão distribuídos em outras 24 igrejas, inclusive em algumas oriundas do protestantismo tradicional. Logo, o segmento evangélico se tem feito representar em praticamente toda a sua diversidade no parlamento. De igual modo, salvo Mato Grosso do Sul e Tocantins, todos os estados brasileiros enviaram representantes evangélicos à Câmara em 2014, o que demonstra a capilaridade social do grupo ao longo do território nacional. E justamente por estarem disseminados e fragmentados em diversos partidos, igrejas e estados da federação, esses deputados são capazes de ocupar espaços simultaneamente no governo e na oposição, o que também permite que não se apresentem, nos casos em que parecer conveniente (escândalos de corrupção que afetem um dos seus pares, por exemplo), como um bloco orgânico, formalizado e plenamente identificável.

Diante de tamanha heterogeneidade, pareceria prudente pôr em xeque a coesão da bancada evangélica. Realmente, "a questão da existência de uma identidade entre os 'políticos de Cristo' é controversa e é pautada em um debate que se baseia em aspectos teológicos, históricos e também ideológicos" (Borges, 2009, p. 159). Em trabalho que sintetiza a discussão e apresenta mensurações baseadas em elementos colhidos dos discursos de parlamentares evangélicos, Gonçalves chega a sugerir que "não existe uma bancada evangélica, ou seja, algo que oriente estes deputados a votarem em bloco" (Gonçalves, 2011, p. 198). De igual modo, Cassotta (2016) conclui que, "embora nas comissões possa haver espaço de defesa das prioridades desse grupo", "as regras internas da Casa convergem para os deputados agirem como um time na defesa de questões gerais cujos resultados podem beneficiar a reeleição da bancada partidária, não facilitando a defesa de uma produção legislativa específica de um segmento" (Cassotta, 2016, p. 97).

De fato, desconhecemos estudos que porventura tenham demonstrado o padrão de votação da totalidade dos membros da bancada em um amplo rol de votações

\footnotetext{
13 Variam os números quando está em questão o tamanho da bancada. Como ilustração, Tadvald (2015) contabiliza 70 parlamentares, ao passo que Silva (2015) computa 84. Uma vez que essa divergência se repete em vários estudos, optamos por adotar como referência a contagem do Diap, entidade que possui reconhecimento no que tange ao acompanhamento das atividades parlamentares, tendo suas informações sido apropriadas, inclusive, pelos documentos publicados pela própria Câmara dos Deputados (ver o relatório institucional de Backes, 2015).

14 O PRB detém 15 parlamentares, ao passo que o PSC possui 9 e no PR estão filiados 7 deputados.
} 
(empresa que é dificultada, inclusive, pelo grande número de votações não nominais). Como qualquer grupo de pressão que opera na política, tais parlamentares possuem singularidades ideológicas ( $\mathrm{e}$, no caso, teológicas), reproduzindo também clivagens regionais e divergências em relação à participação ou não em postos administrativos de governos constituídos.

No entanto, ao menos algumas das principais lideranças dessa bancada apresentam similaridades discursivas, mobilizando com frequência categorias identitárias conservadoras e/ou de "direita". Marco Feliciano, pastor e deputado federal que gerou intensos debates quando esteve à frente da Comissão de Direitos Humanos e Minorias, afirma:

O Brasil, na sua grande maioria, é conservador. Só que é feito de conservadores silenciosos. Talvez falte a eles oportunidade de ter vez e voz porque trabalham muito, porque têm que cuidar da sua família, porque não cuidam da vida dos outros. Como eles não têm tempo, não se envolvem. Mas as urnas provaram isso. Eu, Jair Bolsonaro, Celso Russomano, somos três políticos de ala conservadora que tiveram uma votação expressiva. $O$ que falta no país hoje, e eu acho que as pessoas buscam isso, são políticos de posicionamento. O político não pode ser maria-vai-com-as-outras, não pode ficar em cima do muro e chutar com os dois pés, não pode ser um político-prostituto, que se vende. Tem que saber o que quer ser (...) (Feliciano, 2015).

Não é diferente a visão do deputado João Campos, líder da Frente Parlamentar Evangélica, que, se assumindo abertamente como "conservador", justifica sua postura precisamente com a ideia de que "a maioria da sociedade é conservadora e a Casa [a Câmara dos Deputados] representa a sociedade" (Campos, 2013).

Na esteira desse tipo de raciocínio, o Partido Social Cristão (PSC) - o qual tem nos evangélicos o núcleo duro de seus militantes e apresentou Pastor Everaldo como seu candidato para as eleições presidenciais de 2014 com uma plataforma liberal no campo econômico e moralista na esfera dos costumes - veiculou, em 28 de maio de 2015, a peça publicitária contendo um dos discursos menos envergonhados exibido em propaganda oficial de qualquer candidatura à presidência da República desde a redemocratização. Eis um trecho:

Entrevistador: O senhor se refere ao que aconteceu no Brasil em 1964 como uma revolução, e não como um golpe. É essa a compreensão do partido?

Nósseis ${ }^{15}$ : O país não tinha outra alternativa senão fazer a revolução contra Jango naquele momento. (...) Houve sim uma orientação no sentido de não se deixar que o Brasil se tornasse uma república comunista. (...). E se fosse

\footnotetext{
15 Trata-se de Vitor Nósseis, fundador do PSC.
} 
o contrário? E se eles [os comunistas] tivessem ganhado essa revolução? Certamente nós todos estaríamos no paredão. Você não se iluda. Se houve algum desvio na época militar, e pode ter havido, foi cem mil vezes menor do que o que está acontecendo agora: o governo socialista do seu Lula e da dona Dilma.

Entrevistador: 2015 é igual 64?

Nósseis: Tem alguma coisa parecida sim...

Entrevistador: O PSC e o senhor seriam favoráveis, mesmo que momentaneamente, a uma intervenção militar, como alguns grupos têm pedido?

Nósseis: Nós temos que nos preparar. (...) Nós temos que ter Forças Armadas fortes (...) para nos defender. Eu acho o Feliciano um deputado muito valoroso. Ele conseguiu alavancar o partido, conseguiu demonstrar algumas posições do partido.

Entrevistador: O slogan do partido é "o Ser Humano em primeiro lugar". Não parece contraditório que um partido que use este slogan, por exemplo, ponha barreiras à aprovação dos direitos civis aos casais homossexuais?

Nósseis: O homossexualismo está aí desde tempos imemoriais. Agora, o que eu sou contra, é você fazer lobby disso, é você fazer propaganda favorável dentro das escolas, é você incentivar através dos meios de comunicação as crianças [a aprovarem o homossexualismo] (PSC, 2015).

Esses dados indicam que, após três décadas de "direita envergonhada", lideranças encontraram na agenda moral o veículo a partir do qual tentam mobilizar a identidade de direita, instrumentalizando-a politicamente. Talvez por isso alguns autores comecem a trabalhar com a categoria de "nova direita brasileira" (Cowan, 2014; Codato, Bolognesi e Roeder, 2015):

A velha direita latina pode ser enquadrada em três statments: i) ligação com as ditaduras militares; ii) defesa radical da não intervenção do Estado na economia; iii) defesa da moral cívica e da família tradicional. A nova direita, que surge como resposta dupla à velha e à ascensão da esquerda, também se divide em três: i) liberalismo econômico, com intervenção limitada do Estado na economia para garantir igualdade de oportunidades; ii) defesa da democracia; iii) defesa radical dos valores da família tradicional (Codato, Bolognesi e Roeder, 2015, p. 127).

Visto que o grupo que até aqui analisamos parece guardar relação com o terceiro statement da "nova direita" acima referida, convém que examinemos brevemente 
algumas das mais emblemáticas facetas do influxo evangélico na realidade política brasileira, destacando, ademais, sua capacidade de moldar políticas que interferem na vida cotidiana dos cidadãos.

\section{Conservadorismo e ação política da bancada evangélica no Congresso Nacional}

Um contexto exemplar para demonstrar o quanto iniciativas "progressistas" do Executivo levantaram forte reação dos conservadores foi o que envolveu o episódio que ficou popularmente conhecido como "Kit Gay". O projeto, oficialmente denominado "Escola sem homofobia", foi formulado pelo governo federal em 2011, objetivando forjar "ações que promovam ambientes políticos e sociais favoráveis à garantia dos direitos humanos e da respeitabilidade das orientações sexuais e identidade de gênero no âmbito escolar brasileiro" ("Escola sem homofobia", 2013, p. 9). Na prática, houve a distribuição de um kit informativo para estudantes das escolas públicas (uma cartilha de 125 páginas precisamente intitulada "Escola sem homofobia", uma série de seis boletins, três vídeos acompanhados de orientações para professores, um cartaz de divulgação e uma carta de apresentação).

A reação vinda de parlamentares evangélicos foi imediata. Membros da FPE inicialmente protocolaram um requerimento para avaliar o material antes que ocorresse sua distribuição nas escolas. O ainda líder da bancada, João Campos, à época justificava a iniciativa:

Houve um momento em que o Ministério da Saúde editou uma cartilha para prevenir doenças sexualmente transmissíveis e a cartilha era uma apologia ao sexo livre, uma cartilha inteiramente pornográfica. (...). Em função desses precedentes é que estamos nos prevenindo. Queremos saber quem elaborou o kit, qual foi a rubrica que pagou, quais os dados que o Ministério da Educação tem para editar este material. (...). Estamos requerendo as informações para poder fazer essa avaliação. Primeiro: se o material proposto está dentro de uma visão pedagógica, dentro daquilo que foi anunciado, se é tão somente para prevenir a homofobia ou se vai além disso, fazendo apologia ao homossexualismo, induzindo à prática homossexual (Campos, 2013).

Diante das repercussões que o tópico gerou na imprensa e no Congresso Nacional, os evangélicos promoveram inflamada campanha contra o kit, mobilizando suas bases em protestos de rua, como aqueles que se consumaram na "Marcha para Jesus"16

16 O evento ocorre anualmente, atraindo multidões por todo o país. É promovido por diversas igrejas evangélicas a fim de expor a fé publicamente e protestar contra iniciativas que contrariam os valores do cristianismo. 
de 2011. Líder de uma das marchas, o pastor Cirino Ferro denunciou o projeto do governo como uma tentativa de "imposição que chega sem consultas prévias à sociedade, induzindo nossos filhos a aderir a coisas com as quais não concordamos" (Ferro, 2011). A atual discussão acerca do projeto "Escola sem partido" atende claramente aos interesses desses setores e pode ser visto como uma forma de impossibilitar que futuros governos progressistas busquem implementar políticas públicas de combate à homofobia e de discussão mais ampla acerca dos problemas de gênero (agenda classificada pelos evangélicos como "ideologia de gênero").

Já no âmbito estrito do Congresso Nacional, membros da bancada evangélica, como típico grupo de pressão, valeram-se de uma manobra política para impedir que a iniciativa do governo fosse adiante. De acordo com matéria vinculada no jornal Folha de S. Paulo, o então ministro da Casa Civil, Antônio Palocci, estava sob forte intimidação em decorrência de denúncias envolvendo o crescimento desproporcional de seu patrimônio pessoal, e lideranças da bancada evangélica usaram esse fato como fator de pressão ao ameaçar convocar o ministro para prestar esclarecimentos à Câmara dos Deputados. Como corolário, o grupo garantiu a obstrução da pauta de votações em plenário até que o governo recuasse, e encaminhou um pedido de composição de Comissão Parlamentar de Inquérito (CPI) e de exoneração do então ministro da Educação, Fernando Haddad, por julgar que o material do "Kit Gay" violaria princípios constitucionais e afrontaria as famílias brasileiras (Folha de S. Paulo, 2011).

Três dias depois que as ameaças de retaliação promovidas pelos evangélicos vieram à luz, o Executivo decidiu cancelar a distribuição do material, em uma declaração que denota a derrota do governo e o poder de pressão dos deputados conservadores.

Ainda sobre o debate em torno dos direitos dos gays, aqueles que se associam à FPE formaram uma das principais barreiras à aprovação do Projeto de Lei $n^{\circ} 122 / 06$, o qual pretendia equiparar a discriminação contra homossexuais ao racismo, o que qualificaria aqueles que a praticam como responsáveis por crime imprescritível e inafiançável. Alguns parlamentares evangélicos, além de manifestarem sua contrariedade nas comissões da Câmara, passaram a difundir volumosas críticas ao projeto nos meios de comunicação e promoveram um abaixo-assinado que somou 1 milhão de assinaturas. A fim de celebrar o feito, lideranças entregaram o documento à presidência do Senado em $1^{\circ}$ de junho de 2011 e, na mesma data, mobilizaram 25 mil pessoas em uma manifestação diante do Congresso a fim de pressionar o parlamento e atrair a atenção da opinião pública (Castro, 2011).

Passados cerca de 20 dias, na Marcha para Jesus, em São Paulo, o pastor Silas Malafaia emitiu seu parecer sobre o projeto de lei:

O STF rasgou a Constituição que, no artigo 226, parágrafo 30, diz claramente que união estável é entre um homem do gênero masculino e uma mulher do gênero feminino. União homossexual uma vírgula. (...). Ninguém aqui vai pagar de otário, de crente, não. Se for contra a família 
não vai ter o nosso voto (...). Eles querem aprovar uma lei para dizer que a Bíblia é um livro homofóbico e botar uma mordaça em nossa boca. Se aprovarem o PL 122, no mesmo dia, na mesma hora, tudo quanto é pastor vai pregar contra a prática homossexual. Quero ver onde vai ter cadeia para botar tanto pastor (Malafaia, 2011).

Seguindo o mesmo raciocínio, Magno Malta, senador pertencente à FPE, considera que:

o Projeto de Lei 122, que concede vários privilégios aos homossexuais, é uma aberração (...). O tão exclamado preconceito vem da minoria na ostensiva e agressiva luta para mudar os costumes. Tentaram até implantar nas escolas uma cartilha impregnada de apologia ao homossexualismo, que, pela força da Presidente da República, nasceu morta. Agora, o Senado Federal tem o dever de sepultar de vez o Projeto de Lei 122 (...). A defesa da ética, da moral e dos bons costumes virou uma luta que atravessa a fronteira da religião e chega ao coração das famílias brasileiras. Religião é religião, família é família, o debate é maior, trata-se de preservar o que tem de mais importante na sociedade, a chamada instituição universal e sagrada. É dever de todos os homens de bem pensar no futuro do país formado por uma geração forte e saudável (Malta, 2011).

Malta evoca valores da tradição, tidos como típicos da direita para Bobbio (1995) e claramente associados aos conservadorismos. Mas os discursos em defesa "da ética, da moral e dos bons costumes" não se restringem aos palanques, e cristalizam-se na prática. Membros da bancada evangélica valeram-se de todos os instrumentos possíveis para fulminar o projeto no cotidiano do Legislativo. O golpe final foi desferido pelo senador evangélico Eduardo Lopes, que viu acatado seu requerimento de apensamento da matéria com 29 votos favoráveis e 12 contrários. Finalmente, o projeto foi arquivado ao final da 54a Legislatura (2011-2015) devido à expiração do prazo regimental, que faculta oito anos para que um projeto seja votado. À semelhança do que acontecera com o "Kit Gay", forças da bancada evangélica exerceram com êxito seus mecanismos de pressão para frear agendas progressistas e defender aqueles que seriam, sob sua ótica, os valores cristãos presentes na sociedade brasileira.

A fim de exemplificar mais um dos casos simbólicos de demonstração de capacidade de mobilização dos religiosos no parlamento, citamos também episódio ocorrido em 10 de junho de 2015. Contrariados com manifestantes que haviam simulado a crucificação de Cristo - substituindo Jesus por um transexual e a sigla "INRI" por "LGBT" -, os evangélicos, em conjunto com deputados católicos, entraram em grupo no 
plenário da Câmara rezando o pai-nosso ${ }^{17}$ a plenos pulmões e exibindo imagens colhidas na "Parada".

Ademais, os deputados bradaram reiteradamente o lema "Viva Jesus Cristo", e distribuíram folders que denunciavam a aplicação de recursos públicos para subsidiar manifestações de grupos homossexuais. A sessão foi temporariamente interrompida e, em seguida, o presidente da Frente Parlamentar Evangélica, João Campos, leu da tribuna a nota de repúdio formulada pelo grupo, a qual continha o seguinte trecho (a nota foi assinada também pelo presidente da Frente Parlamentar em Defesa da Vida e da Família, Alan Rick - PRB-AC - e pelo deputado Givaldo Carimbão - PROS-AL -, que preside a Frente Parlamentar Mista Católica Apostólica Romana): "Os ativistas do movimento LGBT cometerem crime de profanação contra símbolo religioso, ferindo a todos os cristãos ao usarem uma pessoa pregada na cruz, utilizando símbolos do cristianismo de forma escandalosa, zombando e ridicularizando o sacrifício de Jesus" (Portal G1, 2015).

O deputado Rogério Rosso (PDT-DF), autor de projeto de lei que transforma em crime hediondo a discriminação às religiões e a profanação de seus símbolos (atitudes que os evangélicos ordinariamente classificam como "cristofobia"), argumentou, em 2015, da tribuna que os ativistas estariam "fazendo o que ninguém imaginava, que é unir todas as religiões" (Folha de S. Paulo, 10 jun. 2015). Por fim, os deputados, liderados por Anderson Ferreira (PR-PE), endereçaram ao procurador-geral da República uma representação contra os organizadores da Parada Gay, acusando-os de serem "responsáveis pelo escárnio e vilipêndio da imagem do Senhor Jesus Cristo e da Cruz, pela disseminação de ódio e intolerância religiosa durante o evento" (Ferreira, 2015).

A disputa política empreendida pelos religiosos no Congresso Nacional possui outro agente mobilizador importante: a oposição à descriminalização do aborto. Se é possível que o homossexualismo não seja vislumbrado pelo grosso da população com o mesmo grau de repulsa a ele outorgado pelos evangélicos, a descriminalização do aborto sabidamente sofre significativa resistência em parte do eleitorado.

Seja pela ciência desse fato (e, consequentemente, pelo capital eleitoral que pode gerar), seja pelo estrito zelo à doutrina religiosa, membros da bancada evangélica têm atuado como protagonistas nos movimentos de contenção de legislações menos restritivas ao aborto que tramitam no Congresso Nacional. Segundo pesquisa que realizamos nos anais da Câmara dos Deputados, desde o ano 2000 foram protocolados nada menos que 78 projetos de lei, decretos legislativos, emendas constitucionais e requerimentos voltados à coibição do aborto, ao recrudescimento da lei para os casos em que a prática já é permitida e/ou a pedidos de esclarecimentos por parte de autoridades públicas envolvidas com o tema. Como seria previsível, todas as iniciativas partiram de evangélicos ou de parlamentares pertencentes às bancadas a eles relacionadas.

\footnotetext{
17 A oração pai-nosso não costuma ser recitada pelos fiéis evangélicos, o que não deixa de demonstrar que se tratou de um esforço de aproximação/união entre evangélicos e católicos a fim de defender interesses comuns.
} 
Os projetos guardam estreito vínculo com a pauta das igrejas, e atacam em múltiplas frentes: no aumento da pena para gestantes que praticam o aborto e para aqueles que as auxiliam (por exemplo, o PL-3207/2008, de autoria de Miguel Martini PHS-MG); na conversão do aborto em crime hediondo no Código Penal (como o PL7443/2006, de Eduardo Cunha - PMDB-RJ - e o PL-5058/2005, de Osmânio Pereira PTB-MG); na proposta de obrigatoriedade do registro público da gravidez "para reduzir a prática ilícita do aborto" (PL-7022/2010, de iniciativa do deputado Robson Rodovalho PP-DF), nos pedidos de criação de CPI "para investigar o aborto clandestino" (RCP9/2008, de Luiz Bassuma - PT-BA); na proibição da comercialização de métodos contraceptivos considerados abortivos (como a "pílula do dia seguinte", conforme dispõe o PL-5376/2005, de Marcelo Serafim - PSB-AM); na pretensão de inserir na Constituição Federal a ideia de que "a vida do nascituro se inicia com a concepção" (PEC-571/2002, de Paulo Lima - PMDB-SP); e na convocação de ministros para esclarecer políticas públicas que interfiram nas restrições ao aborto no país (RIC-750/2007, de Marcelo Serafim - PSB-AM - e RIC-2563/2005, de Durval Orlato - PT-SP).

O levantamento revela que as iniciativas extrapolam a clivagem governooposição e o continuum ideológico dos partidos políticos ${ }^{18} \mathrm{em}$ nome do enfrentamento ao aborto e de lealdades confessionais que estão acima da conjuntura política "profana".

O comportamento dos religiosos na Câmara dos Deputados parece estar alinhado à já citada "tese da ameaça" analisada por Hirschman (1992). No caso do comportamento dos parlamentares citados até aqui, parece claro que questões como a ampliação dos direitos dos homossexuais e a legalização do aborto são encaradas como custos elevados, que põem em xeque realizações preciosas já cristalizadas na sociedade: a família tradicional e a moral cristã.

Se tais agendas ameaçariam os valores nos quais os religiosos depositam sua crença mais cara, a "tese da ameaça" fica ainda mais visível quando se percebe que líderes da bancada evangélica (eventualmente conjugados com parlamentares da bancada católica e da bancada da família), pelo peso político que potencialmente representariam, enfrentam governos e facções rivais com ameaças literais, que vão do trancamento das votações à abertura de processos políticos ou judiciais e à incitação da opinião pública para direcionar resultados eleitorais (como no caso da pressão sobre os candidatos presidenciais em face do aborto, em 2010).

\section{O conservadorismo "laico": o problema da segurança pública e a bancada da bala}

Valores que poderiam ser conectados com determinadas correntes do conservadorismo englobam elementos morais (como a valorização da religiosidade e a

18 Cabe ressaltar que os dois deputados então filiados ao PT acima citados posteriormente deixaram o partido justamente em função de suas posições em relação à questão do aborto. 
oposição a condutas sexuais heterodoxas e ao aborto) e sociopolíticos (como o apreço por instituições tradicionais e pela hierarquia, bem como, por vezes, a rígida punição àqueles que atentam contra a ordem - nesse caso, a ordem jurídica). Se o primeiro rol de princípios vem sendo instrumentalizado politicamente por parlamentares ligados ao cristianismo, o segundo, especialmente no que diz respeito ao combate à criminalidade, vem pautando a ação de parlamentares agrupados na chamada bancada da bala, inspirando o viés laico do atual conservadorismo brasileiro.

$\mathrm{Na}$ legislatura eleita em 2014, deputados vinculados à questão formalizaram a criação de uma bancada dedicada exclusivamente à formulação de políticas de promoção da segurança pública: a Frente Parlamentar da Segurança Pública, que congrega 287 parlamentares ${ }^{19}$, devendo-se ainda somar a Frente Parlamentar pelo Direito da Legítima Defesa (criada em dezembro de 2012 e que então agregava 202 parlamentares ${ }^{20}$ ) e a Frente Parlamentar de Apoio à Família Militar (206 deputados) ${ }^{21}$.

A intensidade do problema da segurança pública no Brasil - especialmente nas grandes cidades - é preocupante o suficiente para atrair uma plêiade de parlamentares interessados em trabalhar por melhorias ou simplesmente buscar incremento de capital político. Logo, a exemplo do que ocorre com as Frentes Parlamentares de cunho religioso, não seria aceitável concluir que a totalidade dos parlamentares pertencentes às forças de segurança atue de forma homogênea e/ou tenha as mesmas preferências.

Porém, conforme sustenta o Diap, há um núcleo duro de 21 deputados que se enquadram nesse perfil, compondo a bancada da bala (ou bancada policial)22, o que parece evidenciar que estão em ascensão tentativas de recrudescimento da lei penal e de aumento da repressão à criminalidade:

A Bancada da Bala é a representante política de um conjunto de ideias e atitudes, que se fundamentam na percepção de que o contexto social está marcado por uma crescente e constante insegurança e desordem pública radical. (...). Haveria um excesso de liberdade e uma perda de autoridade das instituições, sustentada pela incapacidade das leis democráticas e do Estado de Direito de promover a ordem (Berlatto e Codato, 2015, p. 150).

\footnotetext{
19 Ver lista completa em: <http://www.camara.gov.br/internet/deputado/frentes.asp>. Acesso em: 15 nov. 2017. É certo que parlamentares irmanados por interesses similares já atuavam em legislaturas passadas. Contudo, foi a partir do Congresso eleito em 2014 que se formalizou uma Frente Parlamentar e que o tema passou a exercer maior influxo na mídia e na opinião pública.

20 Ver lista completa em: <https://www.camara.leg.br/internet/deputado/frenteDetalhe.asp?id=53423>. Acesso em: 15 nov. 2017.

21 Ver lista completa em: <http://www.camara.leg.br/internet/deputado/frenteDetalhe.asp?id=53717>. Acesso em: 15 nov. 2017.

22 Embora o portal oficial da Câmara dos Deputados na internet insira no grupo 20 parlamentares. Ver <http://www2-.camara.leg.br/camaranoticias/noticias/POLITICA/475579-NOVA-BANCADA-DA-SEGURANCA-DEFE-NDERA-TEMA-S-COMO-REDUCAO-DA-M-AIORIDADE-PENAL.html>. Acesso em: 15 nov. 2018.
} 
À semelhança do que ocorre com os pastores que migram dos "cultos" para o plenário, policiais e militares se convertem em deputados a fim de labutar pela preservação de valores/interesses comuns, freando pautas ordinariamente suscitadas por grupos de direitos humanos (e progressistas de um modo geral). Assim, o modus operandi da bancada da bala igualmente nos permite considerá-la como um autêntico grupo de pressão de cariz conservador que se instalou no interior do Congresso Nacional.

Também de modo similar a algumas lideranças dos evangélicos, a mobilização da identidade de direita vem sendo requisitada pelos membros mais proeminentes da bancada da bala. Referindo-se ao debate em torno da revogação do Estatuto do Desarmamento, o deputado Rogério Peninha Mendonça (PMDB-SC) afirma: "Ano passado tínhamos um equilíbrio de opiniões contrárias e a favor na comissão, apesar de, na minha visão, ele ter se mostrado mais voltado para a revogação. Acho que agora o ambiente será ainda mais favorável, com a Câmara dos Deputados mais conservadora, mais próxima da direita" (Mendonça, 2015).

Já o deputado Delegado Eder Mauro (PSD-PA) assegura que "Serei a voz da direita do povo de Belém em Brasília para apresentar projetos que possam dar um basta nesses vagabundos [os criminosos]" (Mauro, 2014), ao passo que o deputado Jair Bolsonaro (PSL-RJ), um dos mais enfáticos parlamentares da bancada da bala, é sobremaneira conhecido, por exemplo, por defender o regime militar e combater acidamente as esquerdas. Ex-capitão do Exército e deputado federal mais votado no Rio de Janeiro em 2014, Bolsonaro afirma: "Sou de direita mesmo e não tenho vergonha de dizer. Vou disputar o Planalto. (...) É uma candidatura de direita, sem vergonha" (Bolsonaro, 2014) 23 .

Com efeito, a bancada faz-se representante daquela parcela da sociedade que manifesta franca inflexibilidade diante dos criminosos e outorga grande prestígio às Forças Armadas e instituições análogas. Em face disso, os parlamentares da bancada da bala protocolam projetos que visam, por exemplo, a proteção dos agentes policiais, a facilitação do porte de armas para os civis e a redução da maioridade penal.

No primeiro caso, pode-se enquadrar o Projeto de Lei $n^{\circ} 19 / 2015$, de iniciativa do deputado federal Leonardo Picciani (PMDB-RJ). O projeto contou com inúmeras emendas dos parlamentares da bancada da bala, foi aprovado pelo Senado federal e sancionado pela presidência da República em julho de 2015. De acordo com o texto, torna-se crime hediondo o assassinato de policiais ou integrantes das Forças Armadas e do Sistema Prisional quando estes estiverem no exercício da função ou forem assassinados devido ao cargo que ocupam. A proposta foi deliberada na Câmara sob forte pressão de deputados das bancadas da bala e evangélica, que permaneceram em

\footnotetext{
${ }^{23}$ Embora não tenha logrado êxito em concorrer ao cargo máximo do país na eleição de 2014, no momento em que este artigo era escrito (maio de 2018), Bolsonaro ocupava posição de destaque nas pesquisas de intenção de voto para as eleições presidenciais de 2018, erguendo também algumas das bandeiras de combate da bancada da bala.
} 
pé, ao lado do presidente da Câmara, Eduardo Cunha (PMDB-RJ), durante praticamente toda a sessão.

Com relação à posse e à comercialização de armas de fogo, destaca-se o PL n 3722/2012, de autoria do deputado Rogério Peninha Mendonça (PMDB-SC), que prevê a extinção do Estatuto do Desarmamento, aumenta de seis para nove o número de armas legalmente adquiridas por cidadão, abole testes cíclicos voltados à comprovação da aptidão técnica para o manuseio de armas, promove o aumento da quantidade de munição permitida por pessoa (de 50 para 600 projéteis a serem comprados por indivíduo/ano) e reduz a idade mínima exigida para a obtenção do porte de arma: de 25 para 21 anos.

O deputado Onyx Lorenzoni (DEM-RS), um dos apoiadores do projeto, argumenta que o referendo que consultou a população sobre a questão em 2005 gerou uma resposta clara, que deveria ser respeitada pelo governo: "Quero falar um pouco de vida real. (...) Porque nunca antes 60 milhões de brasileiros demonstraram na urna, claramente, a sua vontade - que tem sido negada pelo atual governo (Dilma Rousseff), de maneira peremptória" (Lorenzoni, 2014).

No entanto, a bancada da bala vai além de propor dispositivos que preservam os policiais e ampliam a capacidade de compra de armamentos por parte da população. Deputados daquele agrupamento investem também na modificação da legislação que disciplina a maioridade penal. Em 7 de abril de 2015, a presidência da Câmara dos Deputados, após intenso lobby promovido também por membros da bancada da bala, constitui comissão especial para debater o tema. De fato, pesquisa por nós realizada nos anais daquela casa legislativa revela que, apenas no ano de 2015, 17 projetos de lei ou emendas constitucionais foram protocolados por membros da bancada da bala a fim de promover a redução da maioridade penal de 18 para 16 anos ou de endurecer a aplicação de medidas de restrição de liberdade para adolescentes.

Na justificativa da Proposta de Emenda à Constituição n 32, de 2015, pode-se ler:

Segundo enquetes e pesquisas realizadas pelo Instituto DataSenado entre os anos de 2007 e 2015, mais de $80 \%$ dos entrevistados são a favor da redução da maioridade penal. Mais de $30 \%$ acreditam que 16 anos é a idade mínima para que um indivíduo seja considerado penalmente imputável, isto é, que possa ser julgado pela prática de crime, seja como autor ou partícipe. Mais de $15 \%$ querem reduzir a maioridade penal para 14 anos de idade, e $16 \%$ defendem 12 anos. (...). As leis no Brasil precisam acompanhar a realidade dos fatos e se atualizar com eficiência. O Código Civil já reduziu a maioridade civil de 21 para 18 anos, igualando-a com a idade de imputabilidade penal. Já está passando da hora de dar mais um passo. (...). É inegável que o cidadão dessa idade está plenamente preparado e amadurecido para a maioridade civil e penal, e, portanto, para conquistar a 
vida adulta, com seus direitos e responsabilidades. É evidente que todos devem ter a consciência de se submeter às obrigações previstas nas leis, suportando as sanções decorrentes de sua transgressão ${ }^{24}$.

Nota-se, portanto, que o autor, o deputado Gonzaga Patriota (PSB-PE), valeu-se de dados oriundos da "opinião pública" a fim de fundamentar seus propósitos e, evocando a responsabilização pelos atos cometidos pelos menores de idade, considera que "já está passando da hora de dar mais um passo", ou seja, reduzir a maioridade penal para a idade de 16 anos.

Já na exposição de motivos do PL n 1243/2015 - que, antes de propor a redução da maioridade, requer a revisão das medidas socioeducativas impostas a menores infratores - se verifica a seguinte argumentação:

Ao longo dos últimos anos, o número de crianças e, em especial, adolescentes envolvidos em práticas criminosas aumentou consideravelmente. A progressão dessa situação fez surgir questionamentos na sociedade quanto à adequação do Estatuto da Criança e do Adolescente (ECA) a essa nova realidade social. O presente projeto de lei tem como propósito adequar o Estatuto, aprovado em 1990, à nova realidade social, endurecendo os critérios de aplicação de medidas socioeducativas ${ }^{25}$.

O tom adotado pelo PL $n^{\circ}$ 387/2015 (Alberto Fraga - DEM-DF, que preside a bancada da bala) é consideravelmente mais enfático:

A sociedade brasileira tem assistido o crime organizado aliciar menores para a prática de crimes bárbaros, adolescentes de 12, 14 e 16 anos são utilizados como testa de ferro dessas organizações. Temos visto adolescentes de 17 anos praticarem latrocínio e ao completar 18 anos são postos em liberdade. Essa situação absurda não existe em nenhum local do mundo! Aqueles que se dizem defensores do menor fazem uma colocação distorcida dizendo que os que pedem justiça querem colocar uma criança no presídio. Essa farsa tem que acabar... O que se quer é uma medida justa para que jovens, pais e mães, não sejam trucidados sob o manto de uma suposta menoridade, um ser em evolução! Os falsos defensores de direitos humanos não adotam esses menores, não fazem abrigos para acolhê-los por meio de suas ONGs, mas querem deixá-los nas ruas se drogando e matando! Chega de impunidade, porque esses "doutos" não clamam pelo que temos de mais moderno no mundo? Na Europa e na América do Norte, bem como na América do Sul, o menor é responsabilizado! Por que somente

24 Disponível em: <http://www.camara.gov.br/proposicoesWeb/prop_mostrarintegra?cod-teor=1328804\&fil-ename=PEC+-32/2015->. Acesso em: 15 mar. 2018.

25 Disponível em: <http://www.camara.gov.br/proposicoesWeb/prop_mostrarinte-gra?codteor=1324132\&fil-ename $=P L+1-243 / 201-5>$. Acesso em: 15 abr. 2018. 
no Brasil temos que conviver com esse quadro de desmando e impunidade? A sociedade não aquenta mais, e a prova disso é que os militares e profissionais de segurança pública foram os mais votados no País! Foram votados e eleitos para dar uma resposta, e ela passa por esse projeto e outros que o povo clama. Ressalta-se que nas pesquisas de opinião e de enquete da Câmara e do Senado a redução da menoridade teve o sim de mais de $83 \%$ do povo, e democracia é a vontade da maioria representada ${ }^{26}$.

É nítido o apelo aos setores mais conservadores da sociedade no que se refere ao combate à criminalidade. Censurando "os falsos defensores dos direitos humanos", o deputado sustenta que "a sociedade não aguenta mais" a insegurança e manifestou essa insatisfação mediante pesquisas de opinião e por meio das urnas, que revelaram a ascensão de policiais ao Legislativo com votações expressivas.

Vimos, portanto, que há um grupo de parlamentares bastante ativo que está a valer-se de declarações à imprensa e de projetos de lei para defender valores que, via de regra, se costuma associar à direita e/ou ao conservadorismo. Contudo, resta examinarmos as hipóteses do presente artigo a partir dos discursos dos deputados em plenário, identificando em que medida nos últimos anos foram evocadas categorias como "direita", "conservadorismo" e ataque à "esquerda".

\section{A direita que sai do armário: perfil dos deputados que mobilizam as categorias "conservador" e "direita" e sua relação com as bancadas "evangélica" e "da bala"}

Tendo em vista o complexo pano de fundo até aqui mapeado, parte-se na seção final deste artigo ao teste das hipóteses formuladas. Aqui, a ênfase será dada às manifestações (pronunciamentos) dos deputados federais em plenário. Para tanto, foram avaliados todos os discursos/pronunciamentos proferidos pelos deputados federais entre 2010 (ano em que - na eleição presidencial - questões morais pautaram significativamente o debate eleitoral) e 2017. A fonte utilizada para acessar os pronunciamentos foi a página da Câmara dos Deputados, que contém a transcrição de todos os pronunciamentos proferidos em plenário. O primeiro passo para a análise foi filtrar esse imenso volume de pronunciamentos. Para tanto, utilizamos inicialmente as seguintes palavras-chave: "direita", "conservadorismo" e "conservador(es)".

Em um segundo momento, observou-se que, para além da possibilidade de uma identificação positiva (afirmar-se conservador ou de direita), deputados poderiam lançar mão de uma "identificação indireta", não por meio da identidade de direita/conservador, mas da crítica explícita à "esquerda". Entende-se que ao denunciar, criticar e/ou

26 Disponível em: <http://www.camara.gov.br/proposicoesWeb/prop_mostrarintegra?cod-teor=1301052\&file-name $=P L+38-7 / 201-5>$. Acesso em: 15 abr. 2018. 
condenar a "esquerda", o deputado está indiretamente marcando o seu lugar de fala em oposição a tal campo. Para mensurar também essa questão, incluímos "esquerda" mobilizada enquanto categoria de ataque entre as palavras-chave para a busca dos pronunciamentos a serem perscrutados.

A partir de então, adotamos o protocolo de separar os usos de cada categoria que interessavam à presente análise de todos os demais usos possíveis. A título de exemplo, inúmeras vezes deputados faziam referência a determinado município que ficava "na margem direita do rio $x$ ", ou ao fato de que "as taxas de juros são conservadoras". Outras vezes, os termos eram empregados no sentido ideológico, mas não denotavam o posicionamento do narrador ("direita e esquerda devem se ater ao fato de que..."), de modo que esses casos foram elencados na categoria "outros". Muitas vezes, ainda, tais termos ("conservador" e "direita") eram mobilizados por deputados que se autoproclamavam de esquerda ou de centro enquanto categorias de ataque aos seus interlocutores ${ }^{27}$. Por fim, direita e esquerda também foram mobilizados na negação da validade de tal continuum ("direita e esquerda são categorias ultrapassadas"). Como o foco do artigo é a análise da mobilização dessas categorias enquanto reivindicação de identidade, tais ocorrências foram suprimidas da presente análise.

Tabela 1

Total de incidências das categorias analisadas nos discursos dos deputados federais em plenário (2010-2017)

\begin{tabular}{|l|c|}
\hline & Identidade \\
\hline "Direita" & 40 \\
\hline "Conservadorismo" e/ou "Conservador(es)" & 123 \\
\hline Oposição à "Esquerda" & 361 \\
\hline
\end{tabular}

Fonte: Site da Câmara dos Deputados (dados compilados pelos autores).

Em função da ausência de base comparativa, não podemos identificar se a mobilização de tais categorias em plenário foi maior ou menor do que em períodos anteriores. Mas, levando-se em consideração que a análise cobre um período de oito anos de pronunciamentos, pode-se afirmar que as categorias associadas à identidade de direita foram mobilizadas com frequência relativamente pequena. Nesse universo de pouca mobilização, é digno de nota o achado de que a frequência ocorre mais pela via da identidade de "conservador" do que pela identidade de "direita". Ainda que as incidências de discursos de oposição ao conceito de esquerda tenham sido maiores, a presente análise refuta, com base nesses dados, uma das hipóteses levantadas: a julgar pelos pronunciamentos em plenário, não se verifica nos últimos oito anos uma significativa

27 Embora não seja o foco deste artigo, o uso desses termos enquanto categorias de ataque merece uma análise específica. 
mobilização das categorias "direita" e "conservador" dentre os deputados federais brasileiros.

Outra hipótese levantada é a de que a ação das direitas vem tomando corpo e se fortalecendo ao longo nos últimos anos no parlamento. Contudo, tal hipótese é refutada pela evidência empírica fornecida pela análise da distribuição das frequências com que as categorias "conservadorismo" e "direita" foram mobilizadas enquanto identidade nos discursos dos deputados em cada um dos anos aqui examinados.
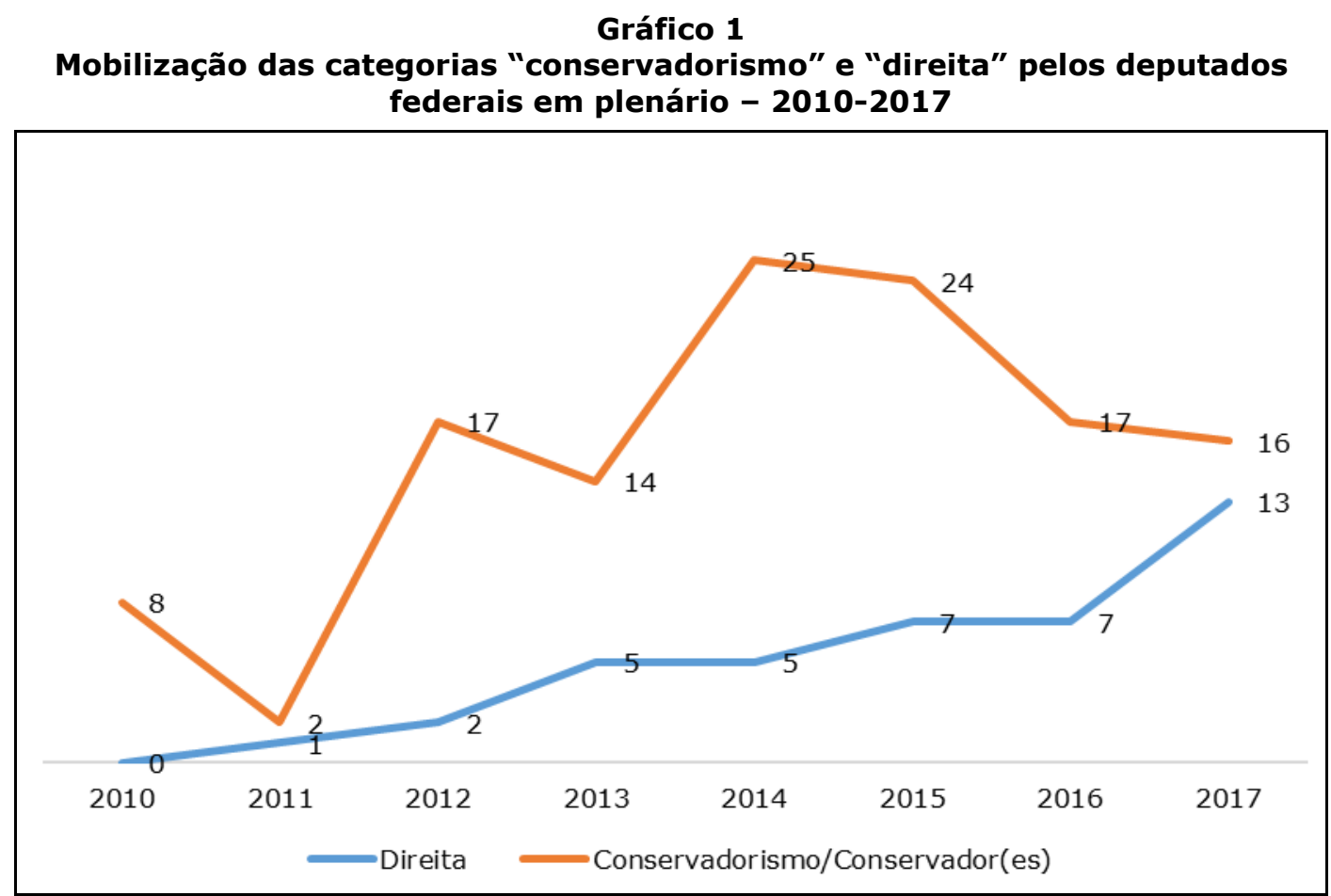

Fonte: Site da Câmara dos Deputados (dados compilados pelos autores).

O Gráfico 1 demonstra que a mobilização de ambas as categorias enquanto identidade política é residual e não sustenta argumento de que a pauta conservadora e/ou de direita esteja ganhando terreno no que se refere aos discursos em plenário. Ao menos não ao ponto de desconfigurar o cenário delineado por Rodrigues (1987). Ou seja: no que tange aos pronunciamentos em plenário, a direita continua envergonhada.

A despeito de a mobilização ser residual, o Gráfico 1 também demonstra que, ao longo do período, ambas as categorias foram mobilizadas nas falas dos deputados. Apesar das oscilações, a identidade de "conservador" mostrou um histórico de maior mobilização, ao passo que a identidade de "direita", ainda que com menor frequência, apresentou um aumento constante de episódios ao longo do período. 
Contudo, é diferente o resultado quando consideramos os discursos que criticam a esquerda, o que pode revelar uma espécie de identidade invertida dos deputados. Conforme exposto no Gráfico 2, fica claro que as ocorrências desse tipo, além de mais numerosas, cresceram consideravelmente, passando de pouco mais de 30 em 2014 para 150 em 2017:

\section{Gráfico 2}

Mobilização da categoria "ataque à esquerda" pelos deputados federais em plenário - 2010-2017

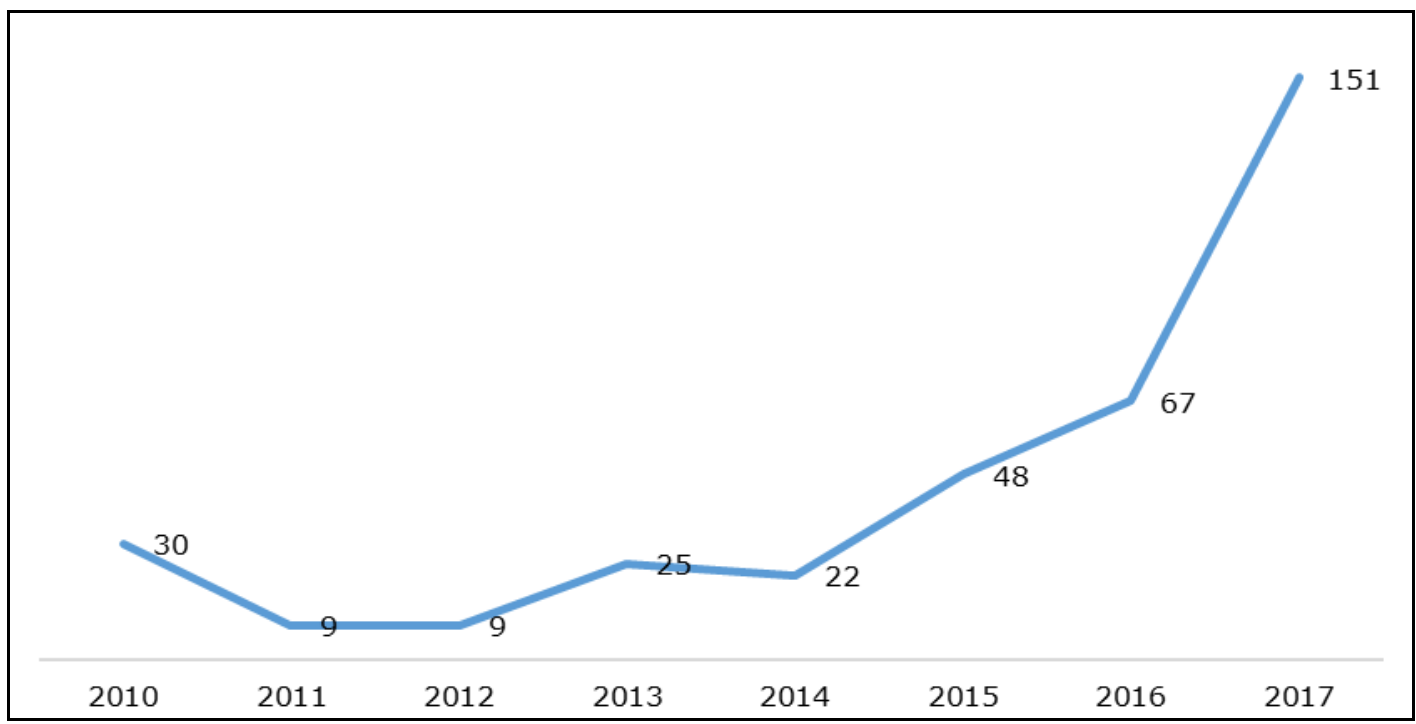

Fonte: Site da Câmara dos Deputados (dados compilados pelos autores).

Pode-se aventar que fatores como o processo de impeachment de Rousseff, o enxugamento do PT nas eleições municipais de 2016 e os danos à imagem de Lula e de outras figuras proeminentes da esquerda após as investigações da Operação Lava Jato tenham impulsionado os pronunciamentos dos deputados em plenário. Logo, estando o adversário combalido, os parlamentares à direita, sem assim se autoproclamarem, cresceram em ativismo e se revelaram indiretamente.

Uma terceira hipótese é a de que os fenômenos aqui analisados ("reação conservadora" e surgimento de uma direita que se assume enquanto tal) são capitaneados por deputados com um perfil bem definido: políticos vinculados às pautas de religião e de segurança pública, que se caracterizam por possuírem carreiras políticas relativamente curtas e por serem desvinculados do regime militar. Para testar essa hipótese examinamos o perfil dos (relativamente poucos) deputados que não são envergonhados (ao menos em plenário).

O universo dos mobilizadores (que chamamos de não envergonhados) é composto de 101 deputados, divididos em dois grupos. O primeiro grupo se refere a grande parte dos 101 deputados que mobilizaram, mas de forma pouco frequente, as 
categorias analisadas (42 deputados valeram-se apenas uma vez de pelo menos uma das categorias em seus discursos durante o período). Ademais, dentre esses 101, 56 não utilizaram nenhuma vez os termos "direita" ou "conservadorismo"/"conservador(es)" como fonte de identidade, mobilizando apenas a categoria "esquerda" (como ataque). Praticamente oito em cada dez "mobilizadores" utilizam a crítica à esquerda e caracterizam-se pela pouca frequência de pronunciamentos. O segundo grupo, por outro lado, caracterizou-se por uma atuação e presença bem mais marcadas enquanto mobilizadores de todas as categorias, bem como pela significativa frequência com que se utilizaram do plenário para mobilizar tais categorias em seus pronunciamentos.

A crítica à esquerda galvaniza a atuação dos mobilizadores: 83 dos 101 deputados lançaram mão de tal categoria, razão pela qual esta não ajuda a estabelecer distinções entre o conjunto dos deputados em tela. Um terço do grupo utiliza-se da categoria "conservador" e apenas um quinto mobiliza a categoria "direita" enquanto identidade. Tal dado permite a hierarquização das pautas que conformam a agenda dos mobilizadores. À luz desse achado, pode-se afirmar que é mais fácil (ou, ao menos, mais recorrente) a crítica à esquerda do que a identificação "ativa" enquanto direita. Além desse aspecto, um conjunto maior de mobilizadores se insere no âmbito do conservadorismo, e o território menos frequentado pelos mobilizadores localiza-se na direita28.

Tabela 2

Categorias mobilizadas por deputado em plenário

\begin{tabular}{|l|c|c|c|}
\hline & Frequência & Percentual & $\begin{array}{c}\text { Percentual } \\
\text { cumulativo }\end{array}$ \\
\hline Conservador & 12 & 11,9 & 11,9 \\
\hline Direita & 2 & 2 & 13,9 \\
\hline Direita/Conservador & 2 & 2 & 15,9 \\
\hline Direita/Esquerda/Conservador & 9 & 8,9 & 24,8 \\
\hline Direita/Esquerda & 8 & 7,9 & 32,7 \\
\hline Esquerda/Conservador & 12 & 11,9 & 44,6 \\
\hline Esquerda & 56 & 55,4 & 100 \\
\hline Total & 101 & 100 & - \\
\hline
\end{tabular}

Fonte: Site da Câmara dos Deputados (dados compilados pelos autores).

Contudo, o mapa das categorias muda significativamente quando aprofundamos os dados e distinguimos os deputados mais atuantes no interior desse universo de 101

\footnotetext{
28 Embora fuja do escopo do presente artigo, esse quadro ficaria mais completo com o levantamento da mobilização do liberalismo econômico enquanto categoria mobilizadora da identidade de direita. Esse será o escopo a partir do qual damos continuidade a este artigo. Tal dado permitirá comparar o peso das agendas econômica e moral e sua relação com a identidade de direita.
} 
mobilizadores. Esse grupo, de apenas dez deputados, mostrou-se extremamente ativo e ideologizado em plenário.

Tabela 3

A elite da direita não envergonhada - Perfil e atuação

\begin{tabular}{|c|c|c|c|c|}
\hline Deputado & $\begin{array}{c}\text { Categoria(s) } \\
\text { mobilizadas(s) }\end{array}$ & $\begin{array}{c}\text { Quantidade } \\
\text { referências } \\
\text { às } \\
\text { categorias }\end{array}$ & Bancada & Partido(s) \\
\hline Jair Bolsonaro & Dir./esq./cons. & 70 & Bala & PP/PSC \\
\hline Marco Feliciano & Dir./esq./cons. & 55 & Evangélica & PSC \\
\hline Antônio Bulhões & Cons. & 42 & Evangélica & PRB/DEM \\
\hline Arolde de Oliveira & Esq./cons. & 26 & Bala/Evangélica & DEM/PSD/PSC \\
\hline Alberto Fraga & Dir./esq./cons. & 23 & Bala & DEM \\
\hline Victorio Galli & Dir./esq./cons. & 22 & Evangélica & MDB/PSC \\
\hline Eduardo Bolsonaro & Esq./cons. & 17 & Bala & PSC \\
\hline João Rodrigues & Esq./dir. & 17 & Bala & DEM/PSD \\
\hline Capitão Augusto & Esq./dir. & 12 & Bala & PR \\
\hline Onyx Lorenzoni & Esq./dir. & 11 & Bala & DEM \\
\hline
\end{tabular}

Fonte: Site da Câmara dos Deputados (dados compilados pelos autores).

Todos os deputados "campeões" na mobilização das categorias pertencem a uma das bancadas aqui avaliadas: bala ou evangélica. Entre as 524 incidências de todas as categorias, esse grupo de dez deputados foi responsável por 295 (56,2\%). Alguns achados são dignos de nota: 1) mesmo que a oposição à "esquerda" seja a categoria acionada pelo maior número de deputados, ela não foi utilizada com exclusividade por nenhum dos membros da elite não envergonhada 29 ; 2) apenas o conservadorismo foi utilizado como categoria exclusiva (e somente por um deputado); 3) se direita e conservadorismo são categorias pouco acionadas entre os 101 mobilizadores, tais categorias são centrais enquanto repertórios da elite não envergonhada (sete dos dez deputados que pertencem ao que chamamos de "elite não envergonhada" mobilizaram uma ou ambas as categorias enquanto identidade); 4) a Tabela 3 também demonstra o quanto os maiores mobilizadores articulam categorias diferentes simultaneamente (quatro dos "campeões" mobilizaram todas as categorias analisadas, o que pode ser um indício de maior consistência discursiva); 5) os dados evidenciam a tendência de que os evangélicos preferem "conservadorismo" à categoria "direita", ao passo que os membros da bancada da bala tendem a preferir a categoria "direita" a "conservadorismo" para mobilizarem suas identidades políticas; 6) os dois primeiros deputados da Tabela 3 (Bolsonaro e Feliciano) respondem por 125 incidências (42,3\% do total de mobilizações produzidas pela elite não envergonhada e $23,8 \%$ de todos os registros de mobilizações analisados); esses dados evidenciam o peso e o papel ativo e de protagonismo desses dois deputados no cotidiano do trabalho legislativo, o que permite argumentar que a

29 Termo a partir do qual passamos a designar esse grupo dos dez deputados mais ativos na mobilização da identidade de direita. 
ampla exposição midiática que esses parlamentares possuem tem lastro em suas atuações em plenário; 7) finalmente, nota-se que sete dos dez deputados dessa elite pertencem à bancada da bala, o que pode indicar um ativismo maior e ainda menos envergonhado por parte dos parlamentares ligados a esse perfil.

O grau de ideologização e de negação do fenômeno da "direita envergonhada" fica evidente no conteúdo de vários dos discursos desse grupo. Como exemplos, pode-se citar o de Arolde de Oliveira de 18 de outubro 2017:

Neste momento em que o globalismo começa a assumir políticas de desconstrução em todos os países e se manifesta em nosso país com os horrores de estímulo à pedofilia, à zoofilia, à erotização das crianças, com ousadia, sem o menor pudor, é muito bom que nós sejamos conservadores. E, como conservadores, vamos reagir ${ }^{30}$.

Já Victório Galli conclama "Quero dizer à Direita do Brasil: vamos deixar de ser meros expectadores. Vamos para a rua. Vamos protestar" (30 out. 2017) ${ }^{31}$. Finalmente, Marco Feliciano se opõe à esquerda nos seguintes termos:

Como se diz que a criatura ultrapassa o criador, o brilhante aluno Partido dos Trabalhadores criou uma extensa rede de ONGs financiadas pela Internacional Socialista, e após ganhar o poder no Brasil, passou a dispor de verbas públicas, em diversos movimentos pseudossociais de proteção aos negros, aos homossexuais, aos indígenas e a todas as minorias que se tornaram fáceis massas de manobras, lideradas por profissionais hábeis em dominar as massas. Para essa esquerda, a única democracia possível é a ditadura do Partido único (...) (11 jul. 2017) ${ }^{32}$.

No que tange aos partidos aos quais os membros desse grupo estiveram filiados durante as legislaturas compreendidas pela análise, importa frisar que há uma sobrerrepresentação do PSC e do DEM (cinco dos dez deputados estão ou estiveram filiados a um desses partidos). Se o PSC, permeado por evangélicos, vem se inserindo no quadro partidário como uma sigla mais recente de tendência conservadora, o DEM,

\footnotetext{
${ }^{30}$ Disponível em: <http://www.camara.leg.br/internet/sitaqweb/resultadoPesquisaDiscursos.asp?txOrador=AROLDE+DE-

+OLIVEIRA\&txPartido $=\&$ txUF $=\& d$ tInicio $=\& d t F i m=\&$ txTexto $=\&$ txSumario $=$ CONSERVADORISMO\&basePesq $=$ plenario\&CampoOrdenacao $=\mathrm{dtSessao \& PageSize}=50 \&$ TipoOrdenacao $=$ DESC\&btnPesq $=$ Pesquisar $\#>$. Acesso em: 13 maio 2018.

${ }^{31}$ Disponível em:

<http://www.camara.leg.br/internet/sitaqweb/resultadoPesquisaDiscursos.asp?txOrador=galli\&txPartido $=\&$ txUF $=\& d$ tInicio $=\& d t F i m=\&$ txTexto $=$ direita \&t $x$ Sumario $=\&$ basePesq $=$ plenario $\&$ CampoOrdenacao $=\mathrm{dtS}$ essao\&PageSize $=50 \&$ TipoOrdenacao=DESC\&btnPesq=Pesquisar $>$. Acesso em: 13 maio 2018.

32 Disponível em:

<http://www.camara.leg.br/internet/sitaqweb/resultadoPesquisaDiscursos.asp?txOrador=marco+feliciano\&txPartido $=\& \mathrm{txUF}=\& d \mathrm{dt}$ Inicio $=\& \mathrm{dtFim}=\& \mathrm{tx}$ Texto $=$ esquerda\&txSumario=\&basePesq=plenario $\&$ Camp

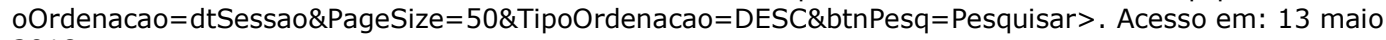
2018.
} 
tradicional partido à direita, acolheu sobretudo deputados da bancada da bala entre aqueles que se destacaram como "campeões" na mobilização das categorias. Se considerássemos o universo de 101 deputados, o PSDB é o partido mais recorrente (25 deputados a ele estiveram filiados em algum momento), seguido pelo DEM (23), pelo PMDB (14), pelo PR (12), pelo PSC (10) e por PRB e PSD 33 (8 cada).

No que diz respeito à trajetória/carreira dos deputados, e seguindo o procedimento adotado neste artigo, estratificamos o universo analisado nas três bancadas em questão (bala, evangélicos e outros) e finalizamos o exame com a apresentação e a discussão de alguns dos achados. Deputados vinculados aos evangélicos e à bancada da bala que se valeram dos mobilizadores são realmente mais próximos de um perfil outsider. Nada menos que $58,3 \%$ dos evangélicos e $47,1 \%$ dos membros da bancada da bala que mobilizaram as categorias são compostos por deputados que conquistaram na atual legislatura o seu primeiro cargo eletivo. No grupo dos sem bancada, tal presença se reduz significativamente: $20 \%$. Se somarmos aos dados os deputados com alguma incipiente carreira prévia (apenas um mandato eletivo conquistado antes da eleição nas legislaturas aqui examinadas), também fica evidenciado que a bancada da bala e os evangélicos apresentam um índice maior de políticos com pouca trajetória pregressa: $79,2 \%$ dos deputados evangélicos que mobilizaram as categorias eram novatos, e $64,7 \%$ dos deputados da bancada da bala estavam na Câmara pela primeira vez. No grupo dos "campeões", cinco dos dez deputados estavam em primeira legislatura, e dois possuíam apenas um mandato anterior. Logo, 70\% do grupo pode ser considerado "novato", o que demonstra que o pouco tempo de casa não inibiu seu protagonismo na farta utilização de discursos ideológicos à direita.

Em síntese, pode-se sugerir que a "reação conservadora" e/ou "de direita" evidenciada nos discursos em plenário é impulsionada sobretudo pela atuação contundente e tenaz de um número pequeno de deputados, os quais se enquadram em um perfil bastante marcado: são altamente ideologizados (e, portanto, pouco "envergonhados"), pertencem à bancada da bala ou à bancada evangélica e tendem a ser outsiders.

\section{Considerações finais}

Ao se fazer um balanço da extensa produção acadêmica acerca da transição para o atual período democrático no Brasil, um dos ingredientes frequentemente citados nos debates sobre reputação ideológica dos partidos, atuação dos partidos na Câmara dos Deputados, estudos de carreira dos deputados federais, estudos sobre identidades partidárias, entre outros, é justamente o fenômeno da "direita envergonhada". Tal fenômeno estaria vinculado ao "fardo" que os principais herdeiros do partido de

\footnotetext{
33 É digno de nota que essa legenda tenha destaque entre os mobilizadores dado que tal achado contrasta com o discurso da direção desse partido (de negação da clivagem direita/esquerda).
} 
sustentação do regime militar (Arena) tiveram que carregar durante as primeiras décadas da transição.

Autores levantam o argumento de que esse fenômeno tenderia a perder influência à medida que mudanças geracionais retirassem do cenário político líderes que sustentaram o regime e os substituíssem por atores sem vínculos diretos com a ditadura. Madeira (2006) mapeou a evolução da presença de ex-arenistas e ex-emedebistas entre os deputados federais eleitos entre 1982 e 2002, indicando que, enquanto na legislatura eleita em 1982, 82\% dos parlamentares haviam sido filiados à Arena ou ao MDB, em 2002, apenas $20 \%$ dos parlamentares estiveram na Arena ou no $\mathrm{MDB}^{34}$. Isto é, a substituição geracional avançou significativamente nas primeiras duas décadas do novo regime democrático.

Porém, trabalhos como os de Power e Zucco Jr. (2009) afirmam que mesmo no fim da década de 2000 a direita ainda permanecia envergonhada. Uma das contribuições que este artigo buscou trazer ao debate foi a de que o mote a partir do qual lideranças relevantes passaram a reivindicar abertamente a identidade de direita não foi o liberalismo econômico que emergiu na década de 1990 (com presença importante na agenda política desde o governo Collor e das privatizações ocorridas sob Fernando Henrique Cardoso), mas o conservadorismo envolvendo questões morais e os apelos de repressão à criminalidade, que ganharam volume a partir de 2010, englobando duas vertentes distintas, mas complementares: a religiosa e a laica.

Argumenta-se também que a mobilização dessas categorias é muito mais reativa do que proativa (configurando aqui mais uma das principais características do conservadorismo), e se dá em função de avanços "intoleráveis" em algumas das "pautas progressistas" no Executivo, no Legislativo e no Judiciário. Bloqueio à expansão dos direitos dos homossexuais e do aborto e recrudescimento da legislação penal: esses são alguns dos principais componentes da agenda em torno da qual surgem sinais mais claros de mobilização, reivindicação e instrumentalização política da identidade de direita no cenário eleitoral e parlamentar no Brasil.

Opondo-se à pauta de parlamentares e defensores dos direitos humanos, essa direita se movimenta de modo a reagir à "ameaça" (Hirschman, 1992), bem como à retificação proposta pelas esquerdas (Lukes, 2003) e à igualdade (Bobbio, 1995), contrapondo a tradição, a ordem e o ceticismo diante da mudança, valores que nortearam o conservadorismo desde Burke.

Novas rodadas de entrevistas com deputados federais, como aquelas realizadas por Power, serão fundamentais para testar se a direita envergonhada está efetivamente perdendo força. O que podemos afirmar aqui é que, além de um antipetismo que parece ganhar musculatura - elemento que não avaliamos no presente artigo -, uma direita conservadora liderada por novos atores tenta ocupar seu espaço sem vergonhas

\footnotetext{
34 Cabe destacar que a mesma análise identificou que entre posições de comando (como a de líder
} partidário) o movimento de substituição foi significativamente mais lento. 
ideológicas, aproveitando-se de um cenário social e político convidativo e do potencial eleitoral que pode vir a ter a defesa de valores que passaram a sofrer contestação nos últimos anos.

Para o mais, o perfil e a origem dos parlamentares que protagonizam esse processo foge às trajetórias políticas mais tradicionais no Brasil e evidencia a emergência de grupos à direita sem relação com o regime militar e sem o ônus político decorrente dessa relação. Nesse sentido, é possível apontar para "o crescimento espetacular dessa nova direita, sua capacidade de atração no mercado de candidatos e por extensão, podemos supor, sua grande penetração social" (Codato, Bolognesi e Roeder, 2015, p. 132):

Novas lideranças incluem essencialmente comunicadores e líderes religiosos. São as ocupações que supomos serem as típicas das bases sociais dos partidos da nova direita. Elas excluem, portanto, advogados, fazendeiros, empresários, sindicalistas, médicos, isto é, as profissões tradicionais de origem da classe política brasileira. São ocupações eminentemente urbanas, com grande apelo popular e alta exposição junto aos eleitores (Codato, Bolognesi e Roeder, 2015, p. 136).

Essa mobilização não está circunscrita a um partido específico - já que perpassa um largo espaço do espectro partidário representado na Câmara dos Deputados - e apresenta tentativas de se conectar com interesses de setores sociais a fim de consolidar e expandir sua plataforma. Conforme verificamos mediante análise de pronunciamentos e projetos de lei oriundos de parlamentares específicos ligados às bancadas evangélica e da bala, as menções à direita, ao conservadorismo ou ao ataque à esquerda não chegam a ser raridade no plenário, e procuram justamente construir interfaces com o eleitorado e com grupos emergentes da sociedade. Pastores migram dos cultos para o plenário do Congresso, ao passo que agentes de segurança saem das delegacias e dos quartéis para combater no parlamento: é o conservadorismo brasileiro que ganha novos contornos, protagonistas e perspectivas.

Resumindo o argumento: as bancadas evangélica e da bala (e, ainda mais especialmente, uma elite parlamentar ideologizada no interior dessas bancadas) constituem-se, efetivamente, na ponta de lança dessa direita não envergonhada. Se tal fenômeno deixará de ser apenas reativo e circunscrito a um pequeno número de deputados, para ganhar musculatura suficiente para se tornar um movimento mais perene e constante, cabe a análises futuras identificar a resposta. 


\section{Referências bibliográficas}

BACKES, A. L. "A 55a Legislatura (2015-2018)". Brasília, Câmara dos Deputados, Consultoria Legislativa, 2015. Disponível em: <http://www2.camara.leg.br/a-camara/documentos-epesquisa/fiquePorDentro/temas/composicao-da-camara-dos-deputados-2015-2019-fev-2015/textobase-da-consultoria-legislativa>. Acesso em: 22 set. 2018.

BerLATto, F.; CodATO, A. Bancada da bala: uma onda na maré conservadora. In: CRUZ, S.; KAYSel, A.; CODAS, G. (orgs.). Direita volver: o retorno da direita e o ciclo político brasileiro. São Paulo: Fundação Perseu Abramo, p. 145-162, 2015.

Bоввіо, N. Direita e esquerda: razões e significados de uma distinção política. São Paulo: Unesp, 1995.

Bolsonaro, J. "Bolsonaro: serei o candidato da direita à Presidência em 2018" [on-line]. O Estado de S. Paulo, 30 out. 2014. Disponível em: <https://politica.estadao.com.br/blogs/marcelomoraes/2014/10/30/bolsonaro-serei-o-candidato-da-direita-a-presidencia-em-2018/>. Acesso em: 15 jun. 2016.

BORGES, T. "Identidade política evangélica e os deputados federais brasileiros". Perspectivas, São Paulo, vol. 35, p. 149-171, 2009.

BURKE, E. Reflexões sobre a revolução na França. São Paulo: Edipro, 2014.

CAMpos, J. "A bancada evangélica e o conservadorismo da sociedade" [on-line]. Entrevista concedida a Assis Ribeiro, Correio Braziliense, 29 jan. 2013. Disponível em:

<https://jornalggn.com.br/blog/luisnassif/a-bancada-evangelica-e-o-conservadorismo-dasociedade>. Acesso em: 2 jun. 2016.

CASSOTTA, P. L. "Uma análise do comportamento dos deputados evangélicos no Legislativo brasileiro". E-legis, vol. 9, n²0, 2016. Disponível em: <http://e-

legis.camara.leg.br/cefor/index.php/e-legis/article/view/259/358 >. Acesso em: 22 dez. 2017.

CASTRO, G. "Religiosos entregam 1 milhão de assinaturas contra projeto que criminaliza homofobia" [on-line]. Veja, 1 jun. 2011. Disponível em: <https://veja.abril.com.br/brasil/religiosos-entregam-1milhao-de-assinaturas-contra-projeto-que-criminaliza-homofobia/>. Acesso em: 5 jun. 2016.

CodATO, A.; Bolognesi, B.; Roeder, K. A nova direita brasileira: uma análise da dinâmica partidária e eleitoral do campo conservador. In: CRUZ, S.; KAYSEL, A.; CODAS, G. (orgs.). Direita volver: o retorno da direita e o ciclo político brasileiro. São Paulo: Fundação Perseu Abramo, 2015.

Coutinho, J. P. Conservadorismo. Lisboa: Dom Quixote, 2014.

CowAN, B. "'Nosso terreno': crise moral, política evangélica e a formação da 'nova direita' brasileira". Varia História, vol. 30, n 52, 2014.

DiAP - Departamento Intersindical de Assessoria Parlamentar. "Atualização da bancada evangélica: Diap identificou 74 deputados", 2014. Disponível em:

<http://www.diap.org.br/index.php/noticias/noticias/24534-bancada-evangelica-levantamentopreliminar-do-diap-identifica-43-deputados>. Acesso: 6 maio 2016.

Escola SEM HOMOFOBIA. Caderno. Brasília: Ministério da Educação, 2013. Disponível em: <http://www.acaoeducativa.org.br/fdh/wp-content/uploads/2015/11/kit-gay-escola-semhomofobia-mec1.pdf>. Acesso: 4 jul. 2016.

Feliciano, M. "'Não sou um deputado da Idade Média', diz Marco Feliciano ao falar sobre política, sexo e religião em Camboriú" [on-line]. Clic RBS, 2 maio 2015. Disponível em:

<http://wp.clicrbs.com.br/guarda-sol/2015/05/02/nao-sou-um-deputado-da-idade-media-diz- 
marco-feliciano-ao-falar-sobre-politica-sexo-e-religiao-em-camboriu/?topo=9-8,2,18, ,15>. Acesso em: 4 jul. 2016.

Ferreira, A. "Representação à Procuradoria-Geral da República" [on-line]. Brasília: 11 jun. 2015. Disponível em: < http://www.folhaesportiva.com.br/ver.php?id=10228>. Acesso em: 13 jun. 2016.

Ferro, C. "Evangélicos protestam contra Kit Gay e criminalização da homofobia" [on-line]. Folha de S. Paulo, 23 maio 2011. Disponível em:

<https://www1.folha.uol.com.br/cotidiano/2011/05/919073-evangelicos-protestam-contra-kit-gaye-criminalizacao-da-homofobia.shtml>. Acesso em: 5 jun. 2016.

FOLHA DE S. PAULO. "Em protesto contra 'kit gay', bancada evangélica mira Palocci" [on-line], 24 maio 2011. Disponível em: <http://www1.folha.uol.com.br/poder/920455-em-protesto-contra-kit-gaybancada-evangelica-mira-palocci.shtml>. Acesso: 7 jun. 2016.

. "Mais conservadora, Câmara deve barrar ações liberalizantes" [on-line], 8 out. 2014. Disponível em: <https://www1.folha.uol.com.br/poder/2014/10/1529052-mais-conservadoracamara-deve-barrar-acoes-liberalizantes.shtml>. Acesso em: 12 ago. 2016.

. "Câmara aprova aumento de isenção tributária a igrejas" [on-line], 6 jun. 2015. Disponível em: <http://www1.folha.uol.com.br/poder/2015/06/1638436-camara-aprova-aumentode-isencao-tributaria-a-igrejas.shtml>. Acesso em: 11 jun. 2016.

"Deputados Evangélicos protestam contra parada gay". [on-line], 10 jun. 2015.

Disponível em: <https://www1.folha.uol.com.br/poder/2015/06/1640504-bancada-evangelica-fazmanifestacao-contra-parada-gay-e-reza-pai-nosso-no-plenario-da-camara.shtml>. Acesso em: 15 nov. 2017.

FREEDEN, M. Ideology. A very short introduction. Oxford: Oxford University Press, 2003.

GonÇALVES, R. "'Bancada evangélica'? Uma análise do discurso parlamentar evangélico durante a $52^{a}$ Legislatura da Câmara Federal". Dissertação de Mestrado em Ciências Sociais. Universidade Federal de Pelotas, Pelotas, 2011.

HiRschman, A. A retórica da intransigência: perversidade, futilidade, ameaça. São Paulo: Companhia das Letras, 1992.

Huntington, S. "Conservatism as an ideology". The American Political Science Review, Cambridge, vol. $51, n^{\circ} 2,1957$.

JUNGBLUT, A. "O 'mercado religioso': considerações sobre as possibilidades analíticas da teoria da 'economia religiosa' para a compreensão da religiosidade contemporânea". Rever, ano 12 , n 2, 2012. Disponível em: <https://revistas.pucsp.br/index.php/rever/article/view/14560>. Acesso em: 18 maio 2016.

KIRK, R. A política da prudência. São Paulo: É Realizações, 2014.

LORENZONI, O. "Câmara pode liberar até nove armas por pessoa" [on-line]. Congresso em Foco, 2 dez. 2014. Disponível em: <https://congressoemfoco.uol.com.br/especial/noticias/camara-discuteliberar-ate-nove-armas-por-pessoa/>. Acesso em: 15 jun. 2016.

LUKES, S. Epilogue: the grand dichotomy of the twentieth century. In: BALL, T.; BELLAMY, R. (orgs.). The Cambridge history of twentieth-century political thought. Cambridge: Cambridge University Press, 2003.

LYNCH, C. E. C. "Conservadorismo caleidoscópico: Edmund Burke e o pensamento político do Brasil oitocentista". Lua Nova, n 100, 2017.

Machado, M. D. Política e religião: a participação dos evangélicos nas eleições. Rio de Janeiro: Ed. FGV, 2006. 
MADEIRA, R. M. "Vinhos antigos em novas garrafas. A influência de ex-arenistas e ex-emedebistas no atual multipartidarismo brasileiro". Tese de Doutorado em Ciência Política. Universidade Federal do Rio Grande do Sul, Porto Alegre, 2006.

MALAfAiA, S. "Marcha para Jesus vira ato contra união homoafetiva" [on-line]. Último Segundo, 23 jun. 2011. Disponível em: <http://ultimosegundo.ig.com.br/brasil/marc-ha+para+je-sus+vira+ato+contra+u-niao+ho-moafetiva/n1597044443203.html>. Acesso em: 18 jun. 2016.

MALTA, M. "Senado vai sepultar PL 122" [on-line]. Website do senador Magno Malta, jun. 2011. Disponível em: <http://magnomalta.com/index.php/pl-122-mainmenu-52/2147-magno-maltasenado-vai-sepultar-pl-122>. Acesso em: 25 jun. 2016.

MANNHEIM, K., et al. A contribution to the sociology of knowledge. London: Routledge and Kegan Paul, 1986.

MARIANO, R. "Laicidade à brasileira: católicos, pentecostais e laicos em disputa na esfera pública". Civitas, vol. 11, $\mathrm{n}^{\circ} 2$ 2, 2011. Disponível em:

<http://revistaseletronicas.pucrs.br/ojs/index.php/civitas/article/view/9647>. Acesso em: 22 jul. 2016.

MAURO, E. "Parentes de políticos e policiais são os campeões de votos" [on-line]. Congresso em Foco, 7 out. 2014. Disponível em: <https://congressoemfoco.uol.com.br/especial/noticias/parentesde-politicos-e-policiais-sao-os-campeoes-de-votos/>. Acesso em: 16 jun. 2016.

MENDONÇA, R. P. "Bancada da bala reabre comissão para tentar derrubar o estatuto do desarmamento" [on-line]. Portal GI, 4 abr. 2015. Disponível em:

<https://ultimosegundo.ig.com.br/brasil/2015-04-04/bancada-da-bala-reabre-comissao-paratentar-derrubar-estatuto-do-desarmamento.html>. Acesso em: 12 jun. 2016.

Miranda, J. Nós, vocês e eles: os desafios de uma convivência (in)desejada. In: BuRITY, J. A.; MACHADO, M. D. (orgs.). Os votos de Deus: evangélicos, política e eleições no Brasil. Recife: Massangana, 2006.

NISBET, R. O conservadorismo. Lisboa: Editorial Estampa, 1987.

Pew ReseARCh Center. "Religião na América Latina. Mudança generalizada em uma região historicamente católica" [on-line], 13 nov. 2014. Disponível em: <http://www.pewresearch.org/wpcontent/uploads/sites/7/2014/11/PEW-RESEARCH-CENTER-Religion-in-Latin-America-PortugueseOverview-for-publication-11-13.pdf>. Acesso em: 11 ago. 2016.

Pierucci, A. F. "As bases da nova direita". Novos Estudos Cebrap, n 19, 1987.

. Ciladas da diferença. São Paulo: Editora 34, 1999.

PORTAL G1. "Deputados evangélicos e católicos fazem ato contra parada gay" [on-line], 10 jun. 2015. Disponível em: <http://g1.globo.com/politica/noticia/2015/06/deputados-evangelicos-ecatolicos-fazem-ato-contra-parada-gay.html>. Acesso em: 13 jun. 2016.

POWER, T. The political right in post authoritarian Brazil: elites, institutions, and democratization. University Park: Penn State Press, 2000.

Centering democracy? Ideological cleavages and convergence in the Brazilian political class. In: KINGSTONE, P.; POWER, T. (orgs.). Democratic Brazil revisited. Pittsburgh: University of Pittsburgh Press, 2008.

POWER, T.; ZUCCO JR., C. "Estimating ideology of Brazilian legislative parties, 1990-2005: a research communication". Latin American Research Review, vol. 44, n 1, 2009.

PSC (PARTIDo Social CRISTÃo). "Horário Gratuito de Propaganda Eleitoral" [on-line]. Youtube, 28 maio 2015, 10 min e $18 \mathrm{~s}$. 
QUADROS, M. P. R. "Conservadorismo à brasileira: sociedades e elites políticas na contemporaneidade". Tese de Doutorado em Ciências Sociais. Pontifícia Universidade Federal do Rio Grande do Sul, Porto Alegre, 2015.

Queiroz, A. A. "Congresso eleito é o mais conservador desde 1964, afirma Diap" [on-line]. Entrevista concedida a Nivaldo Sousa e Bernardo Caram, Estado de S. Paulo, 6 out. 2014. Disponível em: <http://politica.estadao.com.br/noticias/eleic-oes,congresso-eleito-e--o-mais-conservadordesde-1964-afirma-diap,1572528>. Acesso em: 10 maio 2016.

RODRIGUES, L. M. Quem é quem na Constituinte: uma análise sociopolítica dos partidos e deputados. São Paulo: OESP-Maltese, 1987.

SAKAMOTO, L. "O Congresso não ficou pior. Apenas está mais parecido com o Brasil" [on-line]. Blog do Sakamoto, 8 out. 2014. Disponível em:

<https://blogdosakamoto.blogosfera.uol.com.br/2014/10/08/o-congresso-nao-ficou-pior-apenasesta-mais-parecido-com-o-brasil/>. Acesso em: 20 abr. 2016.

SCRUTON, R. O que é conservadorismo?. São Paulo: É Realizações, 2015.

SILVA, G. T. "O Brasil ao pé da cruz: notas sobre a representação política de pentecostais e neopentecostais". Pensamento Plural, n²17, 2015. Disponível em:

<https://periodicos.ufpel.edu.br/ojs2/index.php/pensamentoplural/article/view/5619>. Acesso em: 22 dez. 2017.

TADVALD, M. "A reinvenção do conservadorismo: os evangélicos e as eleições federais de 2014". Debates do NEER, Porto Alegre, ano 16, n०27, p. 259-288, 2015.

Tatagiba, L.; Trindade, T.; Teixeira, A. C. Protestos à direita no Brasil (2007-2015). In: Cruz, S.; KAYSEL, A.; CODAS, G. Direita volver: o retorno da direita e o ciclo político brasileiro. São Paulo: Fundação Perseu Abramo, 2015.

TORRES, J. C. O. O elogio do conservadorismo e outros escritos. Curitiba: Arcádia, 2016.

VINCENT, A. As ideologias políticas modernas. Rio de Janeiro: Jorge Zahar, 1995.

ZUCCo JR., C. "Ideology or what? Legislative behavior in multiparty presidential settings". Journal of Politics, $\mathrm{n}^{\circ} 71$, vol. 3, 2009.

Esquerda, direita e governo. A ideologia dos partidos políticos brasileiros. In: POWER, T.; Zucco JR., C. (orgs.). O Congresso por ele mesmo. Autopercepções da classe política brasileira. Belo Horizonte: UFMG, 2011. 


\begin{abstract}
The end of the embarrassed right? The actions of the "evangelical" and "bullet" caucuses and the paths of conservative representation in Brazil

In the last few years, the reaction of right-wing/conservative groups towards "progressive agendas" has become one of the topics that has sparked the greatest interest among Brazilian researchers in the field of Political Science. This article seeks to contribute to the debate, analyzing the activity of leaders in the Lower House who are tied to the main vectors of this conservative agenda: the "evangelical" and "bullet" caucuses. Therefore, this article examines the speeches and bills formulated by congressmen between 2010 and 2017 arguing that, if it's too soon to state that the "embarrassed right" phenomena is losing strength in the Lower House, it is feasible to suggest that there is a group of representatives gaining significance who are active and ideological, who are relatively disconnected from the traditional political families in Brazil, and who are able to openly mobilize identity categories associated with the right and/or conservatism.
\end{abstract}

Keywords: conservatism; right; evangelical caucus; bullet caucus; speeches

\title{
Resumen
}

¿Fin de la derecha avergonzada? La actuación de las representaciones "evangélica" y "da bala" y los caminos de la representación del conservadorismo en Brasil

En los últimos años, la reacción de grupos de derecha/conservadores al avance de "pautas progresistas" es uno de los temas que más despierta el interés de investigadores de la Ciencia Política en Brasil. El presente artículo busca contribuir para este debate, analizando, en el ámbito de la Cámara de los Diputados, la actuación de liderazgos de dos de los principales vectores de esta agenda conservadora: la "representación evangélica" e la "representación da bala". Por lo tanto, el artículo examina discursos y proyectos de ley formulados por parlamentarios entre 2010 y 2017, argumentando que, si todavía no es posible afirmar que el fenómeno de la "derecha avergonzada" está perdiendo fuerza de modo generalizado en la Cámara de los Diputados, es viable demostrar que gana destaque un grupo de diputados bastante activo e ideologizado, relativamente desvinculado de las familias políticas tradicionales y capaz de movilizar abiertamente categorías identitarias relacionadas a la derecha y/o al conservadorismo.

Palabras clave: conservadorismo; derecha; representación evangélica; representación da bala; discurso

\section{Résumé}

Fin de La "droite honteuse"? L'intervention des courants parlementaires "évangélique" et "de la balle" et les voies de la représentation du conservatisme au Brésil

Ces dernières années, la réaction des groupes de droite/conservateurs pour faire face à l'avancement de "I'agenda progressiste" est l'un des thèmes qui a le plus suscité d'intérêt au sein de la communauté des chercheurs en sciences politiques au Brésil. Cet article vise à contribuer à ce débat en analysant, dans le cadre de la Chambre des députés, I'intervention de deux des principaux vecteurs de ce programme conservateur: les courants parlementaires "évangélique" et "de la balle". Pour ce faire, l'article examine les discours et les projets de loi formulés par les parlementaires entre 2010 et 2017, en faisant valoir que, même s'il n'est pas encore possible d'affirmer que le phénomène de la "droite honteuse" est en train de perdre de la vigueur d'une façon généralisée au sein de la Chambre des députés, il est pertinent de démontrer qu'un groupe de députés très actifs et idéologisés se distingue, se trouvant relativement détaché des familles politiques traditionnelles et étant à même de mobiliser ouvertement des catégories identitaires liées à la droite et/ou au conservatisme.

Mots-clés: conservatisme; droite; courant parlementaire "évangélique"; courant parlementaire "de la balle"; discours

Primeira versão do artigo submetida em 18 de janeiro de 2017. Artigo ressubmetido à publicação em 11 de junho de 2018. Versão final aprovada em 7 de novembro de 2018.

Opinião Pública adota a licença Creative Commons CC-BY. 